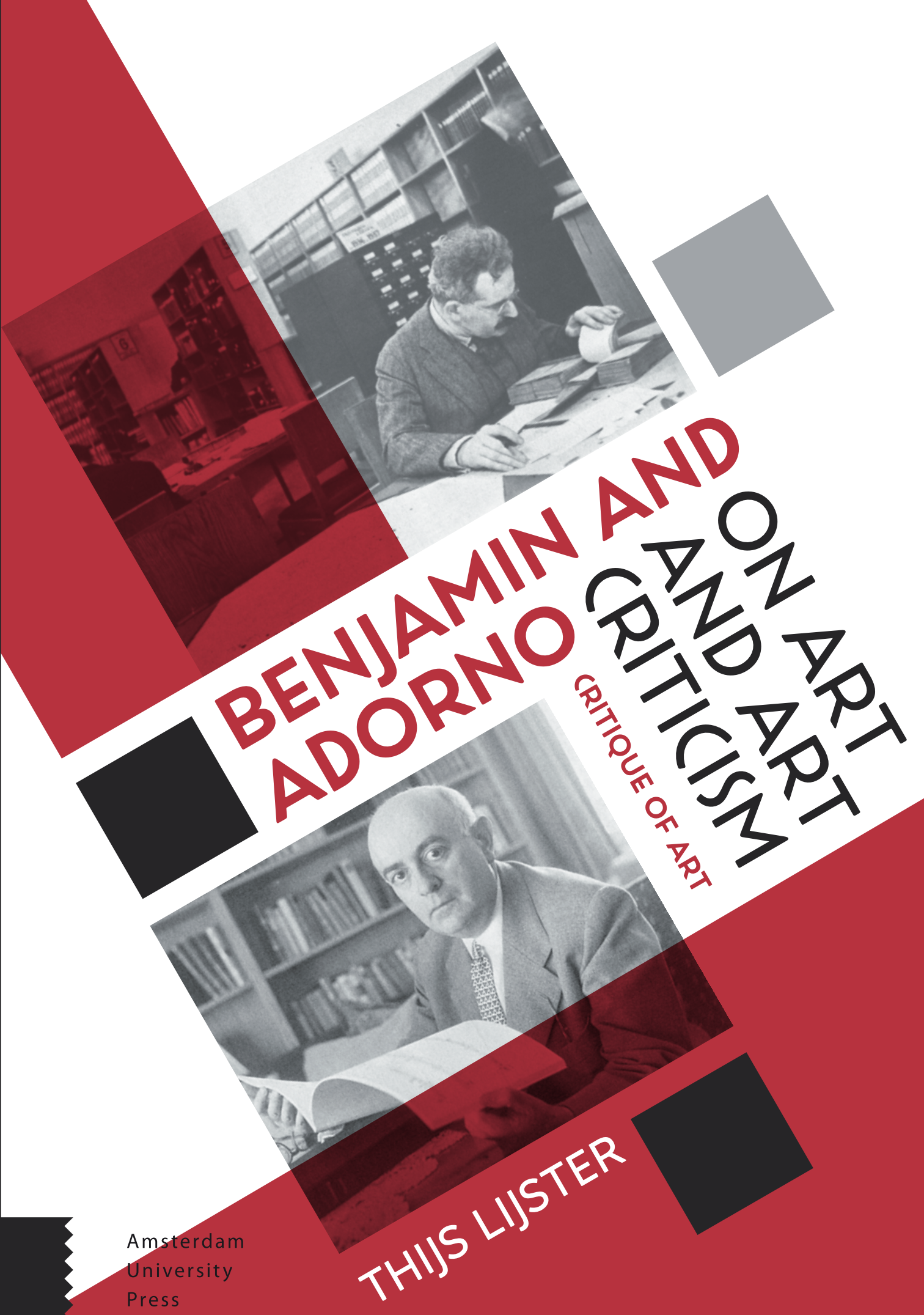


Benjamin and Adorno on Art and Art Criticism 


\title{
Benjamin and Adorno on Art and Art Criticism
}

\author{
Critique of Art
}

Thijs Lijster 
Cover design: Gijs Mathijs Ontwerpers, Amsterdam Lay-out: Crius Group, Hulshout

Amsterdam University Press English-language titles are distributed in the US and Canada by the University of Chicago Press.

$\begin{array}{ll}\text { ISBN } & 9789462981409 \\ \text { e-ISBN } & 9789048531059 \text { (pdf) } \\ \text { DOI } & 10.5117 / 9789462981409 \\ \text { NUR } & 640 \mid 654\end{array}$

(c) T. Lijster / Amsterdam University Press B.V., Amsterdam 2017

All rights reserved. Without limiting the rights under copyright reserved above, no part of this book may be reproduced, stored in or introduced into a retrieval system, or transmitted, in any form or by any means (electronic, mechanical, photocopying, recording or otherwise) without the written permission of both the copyright owner and the author of the book. 


\section{Table of Contents}

Acknowledgements

Abbreviations

Introduction: Critique of Art

1. Autonomy and Critique 19

$\begin{array}{lll}1.1 & \text { Introduction } & 19\end{array}$

1.2 The birth of autonomy 24

1.3 The artist in the marketplace 31

$\begin{array}{ll}1.4 & \text { Art versus society } \\ 10\end{array}$

$\begin{array}{ll}1.5 \text { Conclusion } & 65\end{array}$

2. Ends of Art $\quad 71$

$\begin{array}{lll}2.1 & \text { Introduction } & 71\end{array}$

2.2 Annihilation of semblance: Baroque allegory 72

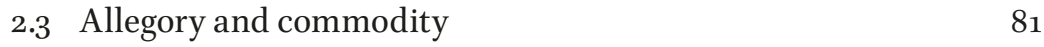

2.4 Proliferation of the aesthetic: technological reproducibility $\quad 87$

2.5 Adorno's dialectic of semblance $\quad 96$

2.6 Culture industry: the social liquidation of art 98

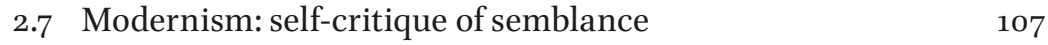

$\begin{array}{ll}2.8 \text { Conclusion } & 119\end{array}$

Excursus I - The (N)everending Story $\quad 123$

Hegel and the beginning of the end $\quad 124$

Danto's post-historical pluralism $\quad 129$

$\begin{array}{lr}\text { Vattimo's weak reality } & 136\end{array}$

Conclusion 142

3. Experience, History, and Art 147

$\begin{array}{lll}3.1 & \text { Introduction } & 147\end{array}$

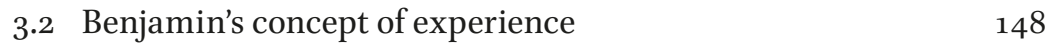

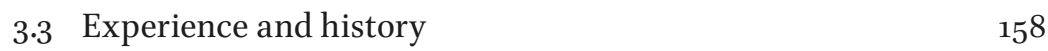

3.4 Art history and monadology $\quad 169$

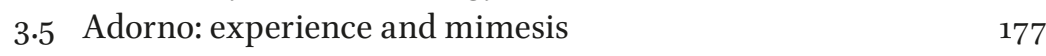

$\begin{array}{ll}3.6 & \text { Natural history } \\ & 189\end{array}$ 
3.7 The tendency of the material and the crystallization of the monad

3.8 Conclusion

Excursus II - Base and Superstructure Reconsidered 207

$\begin{array}{ll}\text { Struggling with a metaphor } & 208\end{array}$

$\begin{array}{ll}\text { A farewell to Marx } & 214\end{array}$

A parallax view on historical materialism $\quad 218$

$\begin{array}{ll}\text { Conclusion } & 225\end{array}$

4. The Art of Critique 229

4.1 Introduction $\quad 229$

4.2 Benjamin's reading of the early German Romantics 230

4.3 Revolutionary criticism 236

4.4 An exemplary piece of criticism: Benjamin's Goethe essay $\quad 250$

4.5 Adorno's immanent criticism 259

4.6 The necessity, and impossibility, of criticism $\quad 267$

4.7 Adorno's Mahler $\quad 277$

$\begin{array}{ll}4.8 \text { Conclusion } & 286\end{array}$

Excursus III - Where is the Critic? 293

Rise and fall of the critic $\quad 294$

$\begin{array}{ll}\text { Why criticism? } & 302\end{array}$

The critic as intellectual $\quad 306$

$\begin{array}{ll}\text { Conclusion } & 311\end{array}$

$\begin{array}{ll}\text { Conclusion } & 313\end{array}$

$\begin{array}{ll}\text { 'A distance, however close' } & 313\end{array}$

The 'actuality' of Benjamin and Adorno $\quad 318$

Critical models $\quad 322$

Post-Fordism and the new spirit of capitalism $\quad 328$

Becoming life versus resistance 333

Appendix - Notes on a Camp 339

$\begin{array}{ll}\text { Bibliography } & 351\end{array}$

$\begin{array}{ll}\text { Index } & 363\end{array}$ 


\section{Acknowledgements}

Der arme Schlucker, der mit leerem Magen über den Büchern sitzt, wird erst

durch ein Werk, das die Menschen aufsehen läßt, zu erweisen haben, daß er etwas anderes ist als ein Müßigganger.

- Walter Benjamin

This book is an abridged version of my PhD dissertation. Therefore, I first of all want to thank the University of Groningen for giving me the opportunity to do the research that lies at the basis of this study. I also want to thank all my former colleagues at the Faculty of Philosophy, as well as my present colleagues at the Arts, Culture and Media department for providing me with such a stimulating working and research environment. I owe a lot to René Boomkens and Rudi Laermans for their help and guidance throughout the years. In 2010, a grant by the Prins Bernhard Cultuurfonds allowed me to spend some time at the New School for Social Research in New York, where I benefitted greatly from the comments of Jay Bernstein on draft versions of my chapters, as well as from his lectures on Kant's third Critique. I thank the Boekman Stichting for encouraging me to find a publisher for my dissertation, by granting me with their triennial dissertation prize in 2015, and I thank my publisher, Amsterdam University Press, for the meticulous reviewing and editing process. I am very thankful for the comments by the reviewers, Anders Johansson and Holger Kuhn, which not only led to some important revisions, but, perhaps more importantly, opened some new paths to future research. The rewriting process was further stimulated by conversations with, among others, Fabian Freyenhagen, Josef Früchtl, René Gabriëls, Samir Gandesha, Pascal Gielen, Johan Hartle, Martin Jay, Leon ter Schure, Jan Sietsma, and Ruth Sonderegger. I also want to thank my friends and family, especially my wife Daniëlle, my son Ruben and my daughter Eline. This book is dedicated to my father and to the loving memory of my mother. 


\section{Abbreviations}

References to the writings of Walter Benjamin and Theodor W. Adorno are given first to the English translations (if available) and then to the German original. Where no English translation was available, translations are my own. With regard to the German original, roman numerals refer to Walter Benjamin (1974-1989) Gesammelte Schriften (I-VII), edited by R. Tiedemann and H. Schweppenhäuser (Frankfurt am Main:Suhrkamp); Arabic numbers refer to Theodor W. Adorno (1973-1986) Gesammelte Schriften (1-20), edited by G. Adorno, S. Buck-Morss, and R. Tiedemann (Frankfurt am Main: Suhrkamp). For references to German texts not included in the Gesammelte Schriften and English translations, I have used the following abbreviations:

ANS Theodor W. Adorno Nachgelassene Schriften, published by the Theodor W. Adorno Archiv. Frankfurt am Main: Suhrkamp.

ABB Theodor W. Adorno and Walter Benjamin (1994) Briefwechsel 1928-1940, edited by H. Lonitz. Frankfurt am Main: Suhrkamp.

ABC Theodor W. Adorno and Walter Benjamin (1999) The Complete Correspondence 1928-1940, translated by N. Walker. Cambridge MA: Harvard University Press.

AP Walter Benjamin (1999) The Arcades Project, translated by H. Eiland and K. McLaughlin. Cambridge MA: The Belknap Press of Harvard University Press.

AT Theodor W. Adorno (1997) Aesthetic Theory, translated by R. Hullot-Kentor. London: Continuum.

BB Walter Benjamin (1966) Briefe (1-2), edited by G. Scholem and Th. W. Adorno (Frankfurt am Main: Suhrkamp).

CI Theodor W. Adorno (1991) The Culture Industry, edited by J. M. Bernstein. New York: Routledge.

CM Theodor W. Adorno (1998) Critical Models, translated by H. W. Pickford. New York: Columbia University Press.

CWB Walter Benjamin (1994) The Correspondence of Walter Benjamin, translated by M. R. Jabobson and E. M. Jacobson. Chicago: University of Chicago Press.

DE Theodor W. Adorno and Max Horkheimer (2002) Dialectic of Enlightenment. Philosophical Fragments, translated by E. Jephcott. Stanford: Stanford University Press. 
EM Theodor W. Adorno (2002) Essays on Music, edited by R. Leppert. Berkeley: University of California Press.

HTS Theodor W. Adorno (1993) Hegel. Three Studies, translated by S. Weber Nicholsen Cambridge MA: MIT Press.

INH Theodor W. Adorno (2006) 'The Idea of Natural History', translated by R. Hullot-Kentor. In: R. HullotKentor (2006) Things Beyond Resemblance. Collected Essays on Theodor W. Adorno. New York: Columbia University Press. 252-269.

ISM Theodor W. Adorno (1976) Introduction to the Sociology of Music, translated by E. B. Ashton. New York: Seabury Press.

ISW Theodor W. Adorno (1971) In Search of Wagner, translated by R. Livingstone. London: Verso.

M Theodor W. Adorno (1992) Mahler. A Musical Physiognomy, translated by E. Jephcott. Chicago: University of Chicago Press.

MM Theodor W. Adorno (1974) Minima Moralia. Reflections on a Damaged Life, translated by E. Jephcott. London: Verso.

ND Theodor W. Adorno (1963) Negative Dialectics, translated by E. B. Ashton. London: Continuum.

NL Theodor W. Adorno (1991-92) Notes to Literature (1-2), translated by S. Weber Nicholsen. New York: Columbia University Press.

O Walter Benjamin (1977) The Origin of German Tragic Drama, translated by J. Osborne. London: NLB.

P Theodor W. Adorno (1981) Prisms, translated by S. and S. Weber. Cambridge MA: MIT Press.

PNM Theodor W. Adorno (2006) Philosophy of New Music, translated by R. Hullot-Kentor. Minneapolis: University of Minnesota Press.

QF Theodor W. Adorno (1992) Quasi una Fantasia: Essays on Modern Music, translated by R. Livingstone. London: Verso.

SW Walter Benjamin (1996-2003), Selected Writings (1-4), edited by M. Jennings et al., translated by E. Jephcott et al. Cambridge MA: The Belknap Press of Harvard University Press. 


\title{
Introduction: Critique of Art
}

\author{
Digressions, incontestably, are the sun-shine; - they are the life, the soul \\ of reading; - take them out of this book, for instance; - you might as well \\ take the book along with them. \\ - Laurence Sterne, The Life and Opinions of Tristram Shandy, Gentleman
}

When, soon after the financial crisis of 2008, several European governments announced plans to cut budgets for art and culture, a heated public debate erupted. The opinion pages in newspapers, and blogs, overflowed with comments from all kinds of people - everyone from representatives of the cultural sector (such as curators, actors, critics and so on) to philosophers, and from politicians to 'the man in the street' - arguing for, or against, the need for art in society. All sorts of demonstrations were organized against the budget cuts, for instance in Italy, Hungary, and the Netherlands. Opponents of the cuts had it that art promotes civilization and solidarity, or brings us into contact with something higher, or with ourselves; that it is a mirror of society, or simply part of our tradition, and for all these reasons deserves government support. Cutting subsidies was considered to be nothing other than a one-way ticket to barbarism. Meanwhile, supporters of the cuts asked why taxpayers should support the extravagance or 'hobbies' of others, or should promote works of art that the general public considered incomprehensible, obscure, or downright banal. Atonal music and avant-garde works such as Duchamp's urinal often functioned as whipping-boys for their arguments.

What was most striking in this public discussion was how difficult it seemed to be to come up with decisive arguments about why art mattered. The autonomy of art, which was dearly won in the eighteenth and nineteenth centuries, now presented itself as a problem: artists and art enthusiasts seemed unable to provide a raison d'etre for what, to them, was evidently valuable. Thus, they unwillingly confirmed the opening lines of Theodor W. Adorno's Aesthetic Theory (1970): 'It is self-evident that nothing concerning art is self-evident anymore, not its inner life, not its relation to the world, not even its right to exist' $(\mathrm{AT}, 1 ; 7,9)$. Adorno was pointing up a crisis in art and aesthetics - a crisis one might describe, following art theorist Jean-Marie Schaeffer, as a legitimation crisis. ${ }^{1}$ In my view, this crisis has by no means ended since Adorno wrote Aesthetic Theory. If anything, it has gotten larger 
and larger, as the debate on subsidies shows. Ever since art emancipated itself from church and state, it has seemed to flail around without a function, while attempts by philosophers and the historical avant-gardes to provide it with a new one have failed. Artists, philosophers, critics and the public have often considered art's unbridled freedom a mixed blessing: the lack of guiding principles and the sense that 'anything goes' raise questions about the value, function and responsibility of art in society. This is precisely why the same question comes up again and again in the course of modernity: Why art?

It is this question around which the present study navigates, although I certainly do not claim to provide the reader with a definitive answer. This question of the function of, and the need for, art can be approached in many ways, but in my view it can never be merely an empirical question. Although sociological research into the actual function of art in people's lives is certainly of interest to me, I am primarily concerned here with the philosophical question of how this function should be considered. My guides in approaching this question are two German philosophers and critics from the early and middle twentieth century, Walter Benjamin (1892-1940) and Theodor W. Adorno (1903-1969). This book is largely an investigation into their work, and into the relations between them. Undoubtedly, their theories are among the most interesting and sophisticated in twentieth-century philosophy of art and art criticism. But, one may ask, why not choose others who, it could be argued, have equal status, such as Georg Lukács or Martin Heidegger, or later thinkers such as Roland Barthes or Jacques Derrida? There are several reasons. First, there are few philosophers who were more acutely aware of the shifts in the social function and significance of art in their time. The interaction between these thinkers - which is documented in their lively correspondence as well as in essays in which they respond to each other- ushers in some of the most crucial and fascinating discussions taking place at the crossroads of aesthetics and politics: on the relation between art and historical experience, between avant-garde art and mass culture, and between the intellectual and the public, to name but a few.

Second, I believe that their work contains certain elements that have been forgotten, neglected or perhaps been too quickly dismissed in contemporary art theory. They emphasize the utopian, emancipatory and critical potential of art - that is, the ability of the work of art to break through, at least momentarily, the mythic veil that capitalism has cast over society. The work of art, they argue, allows us to view history and society in a different light. It is, in their view, nothing less than a bearer of truth. This truth, however, is accessible only through art criticism. The art critic can thus be said, as Benjamin puts it, to 'complete' the work of art. These 
ideas, which were central to Benjamin's and Adorno's work - art as a form of (social) critique, art as a bearer of truth, and art criticism as a condition for disclosing this truth - are not the kinds of idea that are particularly en vogue today. ${ }^{2}$ I deem them crucial, however, to the belief that works of art have something to say to us.

This already points to the subtitle of the present book. It can be read in three ways, each referring to a separate aspect. In the first place, a 'critique of art' can be read in the Kantian sense, namely as an investigation into the boundaries of what art can say or do. In my view, these boundaries are socially and historically determined. That also means that I regard the question that is traditionally central to aesthetics, namely 'What is Art?', as secondary to the question of what art does, that is, of how it functions in the world and why it is important. Here I should mention that, when I speak of art, I have in mind not just the visual arts but also literature and music, which play a prominent part in the writings of Benjamin and Adorno.

The second way in which the subtitle can be read already betrays my hypothesis regarding art's function. As I will argue, art can and should be conceived of as social critique. In arguing this, I am not primarily addressing artists, or urging them to produce so-called 'committed' art and criticize social or political structures. Rather, I want to address theorists of art, and to argue that art should be interpreted as critique and should be granted the social and historical significance it still deserves.

This is not to say, of course, that theorists should ascribe meanings to works of art in any way they please. As I will argue, by putting itself in a reciprocal and transformative relation to the singular work of art, art criticism can function as an 'interpreter' of that work of art and as a 'medium' between it and society. And this brings me to the third meaning of the subtitle. 'Critique of art' refers not only to art criticizing, but also to art that is criticized, namely by art criticism. The German word Kritik can mean both philosophical and social critique, as well as literary and art criticism. Although some theorists argue that these two meanings have nothing in common aside from their etymological root, I will argue that, at least for Benjamin and Adorno, they are inseparably connected. The 'critique of art' depends on art criticism, and hence art criticism is also a form of critique.

The first objective of this study, then, is to shed new light on the work of Benjamin and Adorno, and the relations between their work. To be sure, much has already been written about the famous 'Benjamin-Adorno

2 Nevertheless, in recent years the idea of politically committed art has enjoyed something of a renaissance. I will come back to this point in the conclusion. 
dispute' or 'debate'. Their differences of opinion about the utopian potential of mass culture, for instance, are textbook knowledge and are part of every introduction to cultural or media theory. However, despite the familiarity of this discussion, and arguably even because it has turned into something of a caricature of itself, the precise details of their relationship have hardly been explored. Although their correspondence is elaborately discussed by Susan Buck-Morss and Richard Wolin, for instance, neither of them takes into account Adorno's post-war writings, most notably Aesthetic Theory. ${ }^{3}$ Smaller studies have explored and compared their views on specific subjects, such as philosophical form, photography, and surrealism. ${ }^{4}$ A systematic comparison between these two philosophers, however, has yet to be written. The present study will not be able to fill this void completely, since it is primarily concerned with Benjamin's and Adorno's views on aesthetics and art criticism. More specifically, I will discuss how they address three problems: the 'end of art', the problem of the relation between art and history, and the problem of the relation between art and criticism. Although my investigation will also lead me to their philosophies of history and theories of experience, other domains which would deserve further research fall outside the scope of this book, such as their philosophies of language and their moral philosophy.

The literature on Benjamin and Adorno has focused primarily on the differences between them - their so-called 'controversy' or 'dispute'. They are often set off one against the other, as the representatives of two opposite sides in a debate on mass culture versus elite culture, the one mounting a 'rescuing' critique, the other an ideology critique (Habermas), or a discontinuous as opposed to a teleological (Hegelian) view of history. Furthermore, there is a certain tendency, as Michael Steinberg has observed, to see their relationship as similar to that between Mozart and Salieri, in the sense that Adorno is considered to be the stubborn theoretician fettering the tragic brilliance of Benjamin. ${ }^{5}$

Now, obviously, the differences between these philosophers are considerable, and in the following chapters I will provide a detailed discussion of

3 Buck-Morss (1977), Wolin (1994), Chapter 6.

4 See Weber Nicholsen (1999), Chapters 4 and 5, and Wolin (1997). Some other studies, essays and volumes in which aspects of their thinking are compared are Kaiser (1974), Chapter 1 of Hanssen (1998), Hullot-Kentor (2006) and several of the contributions in Ross (2015).

5 Pensky (1993), 227 (Pensky refers to an unpublished manuscript by Steinberg). In an even more striking simile, Giorgio Agamben compares Adorno to a witch who turns the 'prince of history' into a frog with the 'magic wand of dialectical historicism', while Benjamin is the fair maiden kissing the frog and thus bringing the prince back to life. See Agamben (1993), 133. I will discuss Agamben's view of the Benjamin-Adorno dispute in Chapter 3. 
them. However, in focusing on these differences and disputes, many theorists have tended to overlook the considerable similarities between their theories, thus failing to appreciate the close collaboration and 'philosophical friendship' they themselves spoke of in their letters. In this study, I will regard the relationship between Benjamin and Adorno less as a 'dispute', and more in terms of this philosophical friendship and the mutual influence it entailed. Moreover, Benjamin's influence did not end with his untimely death in 1940. I agree with Britta Scholze's argument that Benjamin, more than any other philosopher, is explicitly or implicitly present in each and every one of Adorno's writings. ${ }^{6}$

In my attempt to bring them closer to one another, I will read the one through the other. This means that, even when they are not explicitly referring to each other, using the same philosophical terminology, or conversing with each other, one can still conceive of their texts as addressing the same problems. ${ }^{7}$ These problems are the ones I have referred to above, and they define the structure of this book. The first chapter, 'Autonomy and Critique', is a historical and sociological prelude to the philosophical problem that is my main concern: that of the function of, and the need for, art in society. I will provide a short 'genealogy' of the autonomy of both art practices and theory, starting with the genesis of the discourse on autonomy in the eighteenth century. Using examples of nineteenth-century and early twentieth-century art that Benjamin and Adorno also addressed, this chapter also functions as a historical contextualization of their aesthetic theories (although I do not explicitly discuss those theories here).

The second chapter, 'Ends of Art', is concerned with the most famous of Adorno's and Benjamin's 'disputes', about the latter's essay 'The Work of Art in the Age of Its Technological Reproducibility' (1936). That essay, I will show, does not stand on its own, but draws on many themes in his early work, most notably from his book on German Baroque drama. Taking into account the context of Benjamin's work-of-art essay, I will argue that his 'dispute' with Adorno is not essentially about mass culture, but rather about the 'end of art'. I thus investigate how the idea of the end, or 'liquidation', of art, as both philosophers sometimes call it, functions in their works. The end of art can mean two things for both: first, the immanent dissolution

6 Scholze (2000), 33. Benjamin himself once said to his cousin Egon Wissing that 'Adorno was my only disciple'. See Eiland and Jennings (2014), 359.

7 I am aware that such a 'homogenizing' way of reading is out of step with the times, especially considering the theoretical reflections on 'oeuvre' and 'authorship' by theorists such as Michel Foucault, Roland Barthes and Jacques Derrida. Nevertheless, I believe it to be a fruitful strategy for reconsidering and rereading certain texts by Benjamin and Adorno. 
of the semblance of the work of art and, second, the proliferation of the aesthetic brought about by technological reproduction. Their debate on the work-of-art essay ultimately comes down to the way they perceive the relation between these two 'versions' of the end of art.

After having concluded in Chapter 2 that art still has a historical role to play, I will investigate how Benjamin and Adorno regard the relation between art and history in the third chapter, 'Experience, History, and Art'. They conceive of the work of art as a repository of experience: the way in which people perceive and interact with their world and with one another is recorded in works of art. Art, in other words, is a medium of experience. However, since experience is, in their view, subject to historical change, works of art are also a form of 'unconscious historiography', as Adorno puts it. They even argue that modernist art should be understood as expressing the experience of the impossibility of experience in modernity. This impossibility of experience is caused by an alienation and a reification of consciousness, which also affect our conception of history itself. Much has been written about Benjamin's critique of the concept of historical 'progress', but Adorno is still often considered an inverted Hegelian who regards history as an unstoppable process of decline. As we will see, however, his philosophy of history draws heavily from Benjamin's, and a fresh reading of it may also shed new light on his philosophy of art history - most notably, his notorious theory of the 'tendency of the musical material'.

In the fourth chapter, 'The Art of Critique', I will show that, according to both Benjamin and Adorno, art criticism is essential both for the ontological existence of works of art and for our experience of them. Both philosophers conceive of works of art as essentially unfinished and fragmentary, and hold that the objective of art criticism is to 'complete' the work. This implies that, even though art still has social and historical significance, it can have this significance only if it is interpreted and criticized. I will point to the similarities and differences between their concepts of criticism, which I will illustrate through a close reading of their texts on Goethe and Mahler.

In each chapter, I will discuss Benjamin and Adorno side by side. Thus, the book is structured somewhat like a fugue, in which a subject is stated and then counter-stated in a dialogic and contrapuntal way, enhancing and contributing to its progressive development. Any discussion of the writings of these thinkers themselves demands an almost musical structuring, as it were, with the same themes and lines recurring in different registers. All their philosophical concepts are linked to each other, and often have a slightly different meaning, depending on the contexts in which they occur. Benjamin once wrote in a letter that he had 'never been able to do research and think 
in any sense other than [...] a theological one, namely, in accord with the Talmudic teaching about the forty-nine levels of meaning in every passage of Torah' (CWB, 372; BB 2, 524). Benjamin's writings, like those of Adorno, demand an almost Talmudic way of reading and interpreting, in which every concept changes according to the passages they are compared with or the problems they are confronted with. And, though I try to do justice to the aesthetic side of their works, any presentation of Benjamin's and Adorno's ideas will inevitably tend to obscure the literary and essayistic aspects of those works, necessarily treating them as content taken out of their form.

Again, in emphasising the close affinity between Benjamin's and Adorno's theories, I do not mean to obscure their differences. I will discuss these at the end of each chapter, as well as in the conclusion to this book. There is a 'distance, however close' between the two philosophers, as Shierry Weber Nicholsen puts it in reference to Benjamin's definition of the aura - that is, differences so subtle that they themselves sometimes overlook them. ${ }^{8}$ Only by putting our finger on these differences, can we recognize the full extent to which their theories overlap. But, as I have suggested above, my attempts to bring Benjamin and Adorno closer are borne not merely of historical interest. There are strategic reasons, too, to reread their work. These reasons comprise the second overall objective of my study: to show that Benjamin's and Adorno's theories, taken together despite the differences between them, could contribute to contemporary debates taking place at the crossroads of aesthetics and politics. I like to think of this strategic reading in terms of a metaphor of Plato, from his dialogue Phaedrus, where he compares the human soul to a charioteer who is driving a chariot. The chariot is being pulled along by two winged horses, which are, however, quite different in temperament, and sometimes wish to go in opposite directions. Benjamin and Adorno too, have their differences, of course, in terms of both opinions and their character, and their work often goes in opposite directions. At the moment, however, I think it is of greater importance to investigate to what extent their thoughts move in the same overall direction.

In his Arcades Project, Benjamin writes: 'The events surrounding the historian, and in which he himself takes part, will underlie his presentation in the form of a text written in invisible ink' (AP, 476; V/1, 595). In other words, the phenomena the historian writes about, and the way they write about them, are influenced by the time in which they live. That is certainly the case for the present study. I have done my research on Benjamin's and Adorno's work, not out of pure historical interest, but based on the 
assumption that their theories are still topical. However, I will be of more service to the reader than the Benjaminian historian by making visible the inscription of the present. This is why I have included, between the main chapters, which are historical and exegetical, three smaller essays. I have called these excursuses, because they digress from the straight path that an academic study would standardly be expected to take. In each excursus, the issue I have just discussed in the preceding chapter is transferred to our own time and examined in light of more-recent debates.

In the first excursus, I will show how the 'end of art' debate reocurred at the end of the twentieth century, after a whole series of end-of... debates that came along with postmodernism. I will discuss how it has been conceived of by several authors, most famously Arthur Danto and Gianni Vattimo. Both of these thinkers, however, neglect crucial aspects of the 'end of art' discussion in Benjamin's and Adorno's work. This allows them to conceive of the end of art as an accomplished fact, instead of a historical chance, as the latter do. But this also means that they cannot account for the need for art in people's lives, and for our society - surely a crucial matter. The second excursus starts from a problem with which we find ourselves confronted at the end of the third chapter: how the artwork relates to history. I will discuss the most notorious historical answer to this question: the base-superstructure model. Although this model has been rightfully criticized, especially the dogmatic variants of it, I look at whether there may still be something to it. By using Benjamin's and Adorno's 'monadology', which I discuss in the third chapter, I attempt to combine historical materialism with what psychoanalytic theory calls the 'parallax view'. The third excursus, finally, deals with an altogether different problem, the role of the intellectual, and most notably that of the art critic. Recently, there has been much debate about the 'crisis' of, or the death or disappearance of, criticism caused by democratization and the loss of aesthetic standards. Drawing on Benjamin's and Adorno's views on art criticism, which I discuss in the fourth chapter, I will argue that the art critic still has an important public role to play in contemporary society.

The excursuses are written in a style somewhat different from that of the main chapters, and are more experimental, adventurous and speculative than they are. They are just first attempts, in the way of hints, to make Benjamin's and Adorno's thoughts fruitful for certain contemporary debates. Juxtaposing past and present, academic form with essay, and historical exegesis with experiment, I follow Benjamin's observation, 'method is digression' $(\mathrm{O}, 28 ; \mathrm{I} / 1,208)$. However, I will leave it up to the reader to determine which parts constitute the real digression. 


\section{Autonomy and Critique}

I! I who called myself a seer or an angel, exempt from all morality, I am restored to the earth, with a duty to seek, and rugged reality to embrace! Peasant! - Arthur Rimbaud, A Season in Hell

\subsection{Introduction}

11 April 1727: At about half past one in the afternoon, in the town of Leipzig, people gather in the Church of Saint Thomas for Good Friday vespers. It is not the first time they have been to church today: this morning they have already been to the Lutheran Mass. It is quiet in the city: the town gates are closed for the day, and iron chains keep traffic away from around the Church.

The people take their seats, and the service starts with the singing of the hymn DaJesus an dem Kreuze stund. The church organ and the orchestra then strike up a beautiful but sad piece, in which two four-part choirs sing of mourning and despair: Kommt, ihr Töchter, helft mir klagen. Suddenly, from above the altar, a third choir of boy sopranos answers with the hopeful and comforting sound of a familiar hymn: O Lamm Gottes, unschuldig. After this choral opening, the story of the Passion according to Saint Matthew is told. It has been set to music by the local cantor, Johann Sebastian Bach, who has been providing the community of Leipzig with new religious music every week for over five years. The churchgoers know the biblical texts and the chorales by heart. The other texts, written by Picander (the pen name of Christian Friedrich Henrici, the postmaster general), consist of reflections on the Gospel written from the perspective of the community of believers. Both Bach's music and Picander's libretto seek to remind the congregation that the suffering of Christ does not lie in the distant past but is happening here and now, in the heart of every individual believer. Between the two parts of the Passion, the minister gives a sermon that lasts about an hour. After the second part, when the last notes of the final chorus have slowly died away, the congregation keeps its solemn silence. The motet Ecce quomodo moritur by Jacob Handl is performed, followed by the offertory and the benediction. Finally, after the singing of the hymn Nun danket alle Gott, the service draws to a close. It is getting dark outside, and the people go back home to have a light meal. They will come back to the church yet again later in the evening. 
Wednesday, 11 March 1829: The beau monde of Berlin gathers in the afternoon at the Singakademie at Unter den Linden to attend a concert by the talented young conductor Felix Mendelssohn-Bartholdy. It is the event of the year, if not of the decade. It has been the talk of the town for weeks, and all the newspapers and journals have announced and written about it. The work to be performed this afternoon is, as a prominent critic has called it, 'the greatest work of our greatest master, the greatest and holiest musical work of all peoples, the great Passion music of Matthew the Evangelist by Johann Sebastian Bach'. It has not been performed since Bach's death, almost 80 years ago. Over a thousand people enter the concert hall, among them royalty, nobility, and intellectuals such as the philosophers Hegel, Schleiermacher, and Humboldt, and the poet Heinrich Heine. Another thousand have to be turned away. On stage are an orchestra, a choir of over 150 singers (more than 6 times the combined size of the choirs that performed in the Church of Saint Thomas in 1727), and the most famous and celebrated soloists of the Royal Opera House. Mendelssohn has been practicing with them for weeks. He has changed the score to accommodate the use of modern instruments, and has cut ten arias, seven choruses and a few chorales to bring the performance down to the standard length of a concert: about two hours.

The audience knows the story of Christ's suffering, of course, but it has no understanding of the Passion tradition. Once the music starts, they marvel at the beauty and intensity of this forgotten piece. The concert is a resounding success, according to both the audience and the critics (with the exception of Heine, who said he had come out ahead because he had paid a guilder but had got a thaler's worth of boredom from the experience). The critic Ludwig Rellstab calls it 'an artistic event of the highest importance'; another critic says it presages 'a new and higher period of music'. That evening, a festive dinner is held in honour of Mendelssohn and Bach. In the months to follow, the Saint Matthew Passion is performed again in Berlin and Frankfurt. ${ }^{1}$

One piece of music, two very different performances. What has changed in the hundred years or so that lie between them? All the specific differences - the size and placement of the orchestra and of the audience, the ceremony and the etiquette, the setting, the ambience, and even the different days of the week on which the performance take place - actually boil down to one key difference: in the first case, people are attending a

1 For these reconstructions, I have used the following sources: Applegate (2005), Boyd (2000), Stiller (1970) and Wolff (2000). 
religious service; in the second, a concert. In the first, the music is fully embedded in the liturgy, and is thus performed and experienced as such. Those in attendance are not an audience but a congregation. In the second case, people come to hear Bach's music, and this music is enjoyed for its own sake. To put it more strongly: in the second case we are dealing with a work of art, in the specific sense that I will elaborate below, whereas in the first case we are not.

According to Karol Berger, one sin endemic to the philosophy of art is to speak of art ahistorically. ${ }^{2}$ We tend to conceptualize and analyse art without realizing that the concept is only about two hundred and fifty years old. Of course, everyone is aware of, and recognizes, the ways works of art have changed throughout history, but what we tend to neglect are the shifts in the very concept of art and the different ways in which this concept has functioned in different eras. We speak of art and beauty in general terms, in the tradition of Kant, who in his Critique of Judgment (1790) mentions hardly any specific artists or works of art and neglects art history altogether. The silent premise behind this sin is that we can have a concept of art that covers all art from all periods, from ancient Greek vases and Christian icons to modern paintings, and from Palestrina's masses to Mahler's symphonies.

The first philosophers to point out the importance of art history for theorizing the concept of art were nineteenth-century German philosophers such as Herder, Schlegel, Schelling, and Hegel. Although Hegel still employed a general definition of artistic beauty as 'the sensuous semblance of the idea', he acknowledged that the nature of the ideas expressed and the way in which they are expressed differ across periods and cultures. ${ }^{3}$ Art, in Hegel's view, is the expression of the way cultures look at themselves. Hence, he considered art history an essential part of the 'science of art', as he described it in the prologue to his Lectures on Aesthetics (1835). Moreover, Hegel argued that art has a specific historical function, which makes it a necessary element of spiritual life during a certain phase in world history, though it will become more or less superfluous later on. ${ }^{4}$

The lesson to be learned from Hegel and the Romantics is that our concept of art today differs as much from, say, Aristotle's as does our concept of 'movement' from his, primarily because both the objects we are referring to and the concepts we are using have different functions at different times.

2 Berger (2002), 109.

3 Hegel (1970), I, 151 .

4 This is, of course, the famous thesis of the 'end of art', upon which I will elaborate below. 
Greek temples or vases, for instance, were in their own time not considered works of art, at least not in our sense of the word. The same goes for an earlyChristian icon, a madrigal from the Middle Ages, or an African mask. ${ }^{5}$ When these objects were created, their social function differed radically from the function they have today, or that contemporary art has. We should subscribe to the dictum of Fredric Jameson: 'Always historicize!' Jameson calls it the one absolute and 'transhistorical' imperative. ${ }^{6}$ This applies especially to such a hybrid, contested concept such as 'art'.

The concept of art, as we know it, is not self-evident; the social function of art has changed over the years and is changing still. A genealogy of art will neither validate nor dismiss the present concept and social function of art, because unveiling the historical process behind a phenomenon is an argument neither for nor against it. However, by locating certain shifts in the social function of art and pinpointing the specific historical conditions that have informed them, we can gain a better understanding of the social function of art in our time. Of course, my interest is not purely historical: I aim to continue what Benjamin calls a 'telescoping of the past through the present' (AP, $471 ; \mathrm{V} / 1,588$ ), by which he meant that our image of the past is as much determined by the present as our understanding of the present is determined by the past.

As many theorists have argued, the most important shifts in the concept and function of art took place at the end of the eighteenth and the beginning of the nineteenth centuries, when art became 'autonomous'.? The autonomy of art is of course a difficult and multi-faceted concept. It can refer to many things, such as the autonomy of the concept of art, the autonomy of the aesthetic experience or judgment, the autonomy of art as an institution, the autonomy of the artist, and the autonomy of the work of art. One could tell a story about each of these distinct autonomies, but in my view it is more interesting to show how they have arisen and how each has influenced the others.

The idea of the autonomy of art is traditionally opposed to the idea that art has a moral or political function. This chapter also discusses the idea of

5 As André Malraux famously wrote: 'The Middle Ages were as unaware of what we mean by the word 'art' as were Greece and Egypt, who had no word for it. For this concept to come into being, works of art needed to be isolated from their functions. What common link existed between a 'Venus' which was Venus, a crucifix which was Christ crucified, and a bust? But three 'statues' can be linked together' (Malraux (1978), 158).

6 Jameson (1981), 9.

7 See, for instance, Bürger (1984), Schmidt (1989), Bell-Villada (1996), Berger (2002), and Woodmansee (1994). 
art as critique, of so-called 'committed' art. Historically, these two ways of viewing art and artistic life - as autonomous or as critically engaged - have been alternately dominant, sometimes coexisting peacefully, but often diametrically opposed to each other. Art was either said to be, in Oscar Wilde's famous words, 'quite useless', or held to be, in a Marxist phrase of disputed origin, 'not a mirror held up to reality, but a hammer with which to shape it.' As we will see, however, the relation between these two different viewpoints is somewhat more complex than this apparently simple either/ or would seem to suggest.

I will start by discussing the birth of the concept of autonomy in eighteenth- and early-nineteenth-century aesthetics, most notably in the work of Kant and Schiller. Their theories mark the beginning of the idea of autonomous art, and have been a constant inspiration for the different 'art for art's sake' movements throughout history. Simultaneously, however, their theories form the basis for modern thinking about a critical or moral function of art. Historical, social and economic conditions help explain how Kant's and Schiller's theories found such a large audience. In the second part of this chapter, I will sketch the way in which the notion of 'art for art's sake' found its way into nineteenth-century artistic life. Kant and Schiller's ideas resonated among artists who found themselves caught between a situation of courtly or clerical patronage on the one hand, and the new free market on the other. Through a discussion of literary life in Paris that focuses primarily on Charles Baudelaire, and of musical life in Vienna, focusing on Mozart and Beethoven, we will see how the artistic market changed the position of the artist, and how both theorists and the public conceived of art and the artist. In the third part of this chapter, I will pinpoint the shifts in the concept of art during the early twentieth century, again in Paris and Vienna, by discussing the Surrealist movement and the work of the composer Arnold Schoenberg.

The choice of Paris and Vienna is by no means arbitrary. These cities, each in their own way, have been crucial for the thought of the protagonists in this study. Walter Benjamin visited Paris many times before living there, in exile, from 1933 until his death in 1940. The Surrealist movement, based in Paris, had a decisive influence on his thinking, while the city, as well as its famous inhabitant Baudelaire, was the primary research subject of his last years. Adorno spent several years in Vienna, taking classes in musical composition with Alban Berg and studying piano with Eduard Steuermann, both of whom were disciples of Arnold Schoenberg. Adorno wrote books on Beethoven, Mahler, Schoenberg, and Berg, and for many years the music of the Second Viennese School was the epitome, for him, of autonomous 
art. Hence, although I do not refer directly to Benjamin and Adorno in this chapter, they will already figure in the background.

\subsection{The birth of autonomy}

The eighteenth century saw the birth of our modern concept of art. In the Middle Ages, and up until the end of the seventeenth century, the various disciplines of what we would today call art fell into two categories: the artes mechanicae and the artes liberales. Painting and sculpture belonged to the former, together with the other crafts and applied arts. The seven liberal arts, which actually also comprised what we today call sciences, were further divided into two categories, each with its own subcategories: three sciences of the word, grammatica, retorica and dialectica, and four of the number: aritmetica, geometria, astronomia and musica. Crafts, arts, and sciences were thus classified quite differently from how they are classified today. ${ }^{8}$

In the course of the seventeenth century, this order was gradually replaced by a separation between arts and sciences on the one hand, and the new distinction between applied (or mechanical) arts and 'fine' arts on the other. An important step towards a concept of art (as distinguished from the plural 'arts') was an essay by the Abbé Charles Batteux, The Fine Arts Reduced to a Single Principle (1746). As the title indicates, Batteux subsumed the different arts - music, poetry, painting, sculpture and dance - under 'fine arts', based on the principle that they give pleasure without having an external purpose. ${ }^{9}$

Following Batteux, a number of German philosophers reflected on the concept of art, and sought to separate and free it from any external purpose it might serve. Gotthold Ephraim Lessing, in his Laocoön (1766), writes:

I should like the name of 'works of art' to be reserved for those alone in which the artist could show himself actually as artist, in which beauty has been his first and last object. All the rest, in which too evident traces of religious ritual appear, are unworthy of the name, because Art here has not wrought on her own account, but has been an auxiliary of religion, looking in the material representations which she made of it more to the significant than to the beautiful. ${ }^{10}$ 
Karl Philipp Moritz published two important texts, Attempt at a Unification of All the Fine Arts and Sciences Under the Concept of That Which is Perfect in Itself (1785) and On the Artistic Imitation of the Beautiful (1788), in which he ascribed intrinsic value to the fine arts. Moritz characterized works of art as 'self-sufficient totalities' and linked beauty to uselessness:

For the concept of the useless, insofar as it has no end, no purpose outside itself for which it exists, is the closest and most willing to connect up to the concept of the beautiful insofar as the beautiful does not need an end, a purpose for existing, except itself, but finds its whole worth, the end of its existence, within itself. ${ }^{11}$

Three decades earlier, Alexander Baumgarten had published the two volumes of his Aesthetica (1750-58), in which he first uses the term 'aesthetics' in its modern meaning. 'Aesthetics' was up until then known as the science of perception. This is the sense in which we can find the term in the work of Descartes and still in Kant's Critique of Pure Reason (1781). With Baumgarten, aesthetics becomes the name of the philosophical discipline specifically concerned with the beautiful. ${ }^{12}$ The notion of an autonomous domain of art was slowly but surely developing in the minds of late-eighteenth-century philosophers, of whom Immanuel Kant was undoubtedly the most important.

The work of Kant marks a turning point and a true 'Copernican revolution' in many branches of philosophy - and his writing on aesthetics was no exception. His Critique of Judgment is a key text of modern aesthetics, introducing or systematically elaborating such notions as 'disinterestedness', 'purposiveness without a purpose', 'genius', and the 'sublime' - concepts that have been central to aesthetics ever since. But we should not be mistaken about Kant's project. Although it is often read this way, the Critique ofJudgment is primarily concerned, not with the question: What is art? but with the transcendental question: How is an aesthetic judgment possible? I will not discuss how Kant attempts to answer this question. What is most important for now is that, in order to answer it, he distinguishes aesthetic judgments from judgments both on the agreeable (for instance, 'This meal tastes nice') and on the good ('This deed is good'). Both kinds of judgment, he holds, are

11 Moritz in Bernstein (ed., 2003), 136.

12 It is worth noting that, for Baumgarten, as for Kant, aesthetics is concerned with both the beauty of nature and the beauty of art, and that both hold the latter to be inferior to the former. The aesthetic theories of Schelling and Hegel reverse this hierarchy for the first time. 
connected with a certain interest (one either desires the object or wants the deed to happen), while aesthetic judgment is 'devoid of all interest'. ${ }^{13}$

Moreover, Kant argues that aesthetic judgments, in contrast to moral judgments, are based, not on a concept of what the beautiful object is, but on a feeling. Nevertheless, and precisely because of their 'disinterestedness', aesthetic judgments make a claim to universality. Because no individual interests are involved in my judgment, there is no reason why everybody should not share it, even if I am unable to give arguments in support of it. The feeling of the beautiful, according to Kant, is grounded in the 'free play' of the cognitive faculties intuition and understanding, which everyone shares - hence his definition of beauty as 'what, without a concept, is liked universally'. ${ }^{14}$ Kant's other famous characterization of beauty as 'purposiveness without purpose' is derived from this. Certain objects are held to be beautiful because they seem fit to fulfil their purpose in nature or society. Kant calls these 'accessory' or 'adherent' beauties, and mentions humans, horses and buildings as examples. But a judgment that objects possess true and 'free' beauty is made without our knowing their actual purpose, even if their sheer form forces us to presuppose such a purpose..$^{15}$

Although Kant was, as we will see, often thought of as one of the founding fathers of the idea of 'art for art's sake', this was never his intention and is far from what he writes. He makes clear that, although the aesthetic judgment should arise autonomously, that implies neither that an interest cannot be attached to it afterwards, nor that a beautiful object could not have an external purpose. ${ }^{16}$ Towards the end of part one of the Critique ofJudgment, Kant even connects beauty explicitly to morality: 'Now I maintain that the beautiful is the symbol of the morally good. ${ }^{17}$ Kant argues that, while moral considerations should play no part in deciding whether an object is beautiful, beauty can indeed play a part in people's moral education.

13 Kant (1987), 211:53. Here and in subsequent references, the page number in the Akademie edition appears before the colon; that in Pluhar's translation of the Critique ofJudgment, after it.

14 Ibidem, 219:64.

15 Ibidem, § $16(229-231: 76-78)$.

16 In $\S 41$ of the Critique ofJudgment he writes: 'That a judgment of taste by which we declare something to be beautiful must not have an interest as its determining basis has been established sufficiently above. But it does not follow from this that, after the judgment has been made as a pure aesthetic one, an interest cannot be connected with it' (Kant [1987], 296:163).

17 Kant (1987), 353: 228. This passage has puzzled many scholars, and is still a point of much debate. However, that debate falls outside the scope of this chapter. See Allison (2001), Chapters 10 and 11, for an in-depth discussion of the relation between disinterestedness and morality. 
Kant does not make any pronouncements on the autonomy of the practice of art, or the social status of the artist. He argues that judgments of the beautiful should be autonomous, in the sense that, in order for a judgment to be purely about taste, it should be disconnected from subjective interests, moral concerns or truth claims. The popularity Kant's theories came to enjoy among artists is mostly because of the mediation of the romantic playwright and philosopher Friedrich Schiller, who complemented Kant's aesthetic theory with anthropology and social critique. In On the Aesthetic Education of Man (1795), a collection of letters to his patron, the Duke of Augustenburg, Schiller describes human beings as torn in two by conflicting forces, which he calls the sensuous and the formal impulses. ${ }^{18}$ In ancient Greece, Schiller argues, these were still in harmony, but in modern society, people's individual development becomes one-sided and distorted. Their impulses constantly strive for domination, and when either of the two gets the upper hand, people turn into either wild animals or heartless intellectuals. As long as they are not able to achieve harmony between these impulses, people have no individual freedom, and without this they are not ready for political freedom. In Schiller's view, the reign of terror following the French Revolution was a clear illustrative example of this inability and this lack of readiness.

Harmony between the two impulses can be achieved, according to Schiller, only through a third impulse, which results from the interplay of the first two: the impulse to play. ${ }^{19}$ Schiller writes: 'For, to declare it once and for all, Man plays only when he is in the full sense of the word a man, and he is wholly Man only when he is playing. ${ }^{20}$ The expression of this impulse to play, according to Schiller, is art, and it is therefore only through art that people can be educated and become truly free.

It seems that Schiller has formulated a clear purpose for art: to educate people, thus bringing about political freedom. And yet he rejects any notion of functional or instrumental art, as he makes clear in his second letter, where he criticizes the way modern society treats its poets:

But today Necessity is master, and bends a degraded humanity beneath its tyrannous yoke. Utility is the great idol of the age, to which all powers must do service and all talents swear allegiance. In these clumsy scales

18 Schiller (1954), 64-67. These two impulses can be considered as anthropological translations of the two Kantian domains, necessity and moral law.

19 Ibidem, 74.

20 Ibidem, 80 (italics in the original). 
the spiritual service of Art has no weight; deprived of all encouragement, she flees from the noisy mart of our century. ${ }^{21}$

Schiller condemns his age and society, in which, he says, everything must have a function or serve a purpose. This attitude, he argues, results in a general hostility towards art and artists, who serve no purpose and have no function. He writes:

We must therefore acknowledge those people to be entirely right who declare the Beautiful, and the mood into which it transports our spirit, to be wholly indifferent and sterile in relation to knowledge and mental outlook. They are entirely right; for Beauty gives no individual result whatever, either for the intellect or for the will; it realizes no individual purpose, helps us to perform no individual duty, and is, in a word, equally incapable of establishing the character and clearing the mind..$^{22}$

In the spirit of Lessing, Moritz and Kant, but more forcefully and emphatically than they do, Schiller formulates here the idea and ideal of an art that exists for no outside purpose, an art that exists only for its own sake and is, indeed, quite useless.

In the work of both Kant and Schiller, we are confronted with the peculiar combination of two ideas about art: as the object of a 'pure' aesthetic experience and as a means of moral or political education. Many scholars have had difficulties reconciling these two seemingly contradictory notions. Siegfried Schmidt argues that Kant's and Schiller's concept of autonomy lays the groundwork for the 'depoliticization' (Entpolitisierung) of art. ${ }^{23}$ Likewise, Martha Woodmansee holds that Schiller, in arguing for the autonomy of art, betrays his original project of emancipation and propagates 'the kind of freedom to dream that is the consolation of the subjects of even the most repressive regimes. ${ }^{24}$ These remarks neglect, in my view, the dialectical character of Schiller's theory, according to which art can be politically meaningful only by refraining from an immediate political function. ${ }^{25}$ Nevertheless, Schmidt and Woodmansee do ask why Schiller would stress

25 As Peter Bürger writes, 'Schiller attempts to show that it is on the very basis of its autonomy, its not being tied to immediate ends, that art can fulfill a task that cannot be fulfilled in any other way: the furtherance of humanity' (Bürger 1984, 44). 
the autonomy of art in his time, and investigate, by way of an answer, the economic and social-historical conditions that can give rise to the autonomy of art (or, in Schiller's case, of literature).

Many factors contribute to the autonomy of the 'social system' of literature, as well as to the genesis of the idea of autonomous art, in the eighteenth century: the professionalization of the author, the development of copyright laws, technological improvements in printing and in the paper industry, the change in the status of the artist from craftsman to 'genius', and, most importantly, the rise and growth of a literate middle class, which in turn led to an enormous increase in the demand for literary works. ${ }^{26}$ Towards the end of the century, nearly 25 percent of the German population was literate - twice as high as it had been a few decades earlier. ${ }^{27}$ Some German critics expressed their worries about this 'reading mania'. A series of journal articles in 1789 and 1790 discussed the 'causes of the contemporary ubiquitous ink-slinging [Vielschreiberei] in Germany. ${ }^{28}$

These developments made it possible for German men of letters to live by the pen, especially because patronage was less common in Germany than it was in France and England. The provincial German nobility, scattered over small city-states and principalities and relatively impoverished after the Thirty Years' War, was generally not that interested in art, and where it was, it preferred French art. ${ }^{29}$ As Norbert Elias argues in The Civilizing Process, the German literary movement of the second half of the eighteenth century was also a social movement that contrasted what it saw as the 'cold reason' and empty rituals of the aristocracy with the true and honest culture of the middle class. The movement's ideal of Kultur was opposed to aristocratic Zivilisation..$^{30}$ According to these writers, the French idea of civilization primarily promoted norms of public behaviour in matters of politics, morals, religion, taste, and so on, and was thus, in their view, superficial, hypocritical and false. They held that culture, by contrast, had nothing to do with behavioural norms and was a matter of honesty and virtue: it concerned one's inner being, and one's deepest emotions and convictions. It was in this ideal of culture, voiced most prominently by Goethe's Werther, that the German middle class invented itself.

26 Schmidt (1989), 286.

27 Woodmansee (1994), 25.

28 Schmidt (1989), 292.

29 Schmidt notes, for instance, that Wieland was first noticed in Germany once his novels had been translated into French (Schmidt [1989], 288n).

30 See Elias (1978), especially $1-35$. 
The new generation of writers thus readily embraced the possibility of writing for a middle-class audience. Woodmansee takes the literary career of Schiller as an example of this generation. In a piece he wrote for a periodical and that was published in 1784 , Schiller boldly declared:

The public is now everything to me, my school, my sovereign, my trusted friend. I now belong to it alone. I shall place myself before this and no other tribunal. It alone do I fear and respect. Something grand comes over me at the prospect of wearing no other throne than the human spirit. ${ }^{11}$

Schiller's enthusiasm for the free literary market did not last long, however. While his play The Robbers (1781) was a great public success, the audience responded coolly to his later works. Theatre managers preferred other playwrights, who could finish a play within a few weeks, to Schiller, who took more than three years to write Don Carlos (1787), for instance. A few years after his paean to the public, Schiller began to realize that there might be a larger reading audience available, but that it was not necessarily interested in his plays or in the work of other esteemed poets such as Wieland and Goethe. Instead, the public wanted to read what he called 'mindless, tasteless, and pernicious novels, dramatized stories, so-called journals for the ladies and the like. ${ }^{32}$ When in 1791 the Danish Duke of Augustenburg offered the impoverished poet a patronage, he jumped at it. And in 1799, fifteen years after he had declared his love for the public, he wrote a letter to his friend Goethe, saying that 'the only possible relationship to the public is war.'33

What does the case of Schiller tell us? First, it shows that he, Lessing, Moritz and Kant produced their philosophical theories on the autonomy of art and of individual works of art against the backdrop of the actual development of an autonomous sphere of art in society. The autonomy of art was, in other words, not just a philosophical theorem or a discourse, but also a social fact. Second, it shows us that the relation of artists towards this newly won freedom was, to say the least, ambivalent. On the one hand, the decline of patronage by the Church and the state was welcomed as a kind of liberation. On the other hand, the new market in which artists were forced to operate brought new constraints with it. This ambivalence would become even more apparent in the two cases I will discuss in the following section. 


\subsection{The artist in the marketplace}

In the preceding section, I touched on the relation between shifts in philosophical theories on the autonomy of art and shifts in the social situation of the artist. In this section, I will elaborate on the changes in the social situation of art and artists by discussing literary life in nineteenth-century Paris and musical life in Vienna. This is not to suggest that this period in the artistic life of Paris or Vienna marks the 'beginning' of autonomous art or artists - speaking of 'beginnings' or 'first times' in history is always precarious. The social situation of art depends on geographical borders and on the art form. One could argue, for instance, that seventeenth-century Dutch Realism marks the beginning of autonomous painting. ${ }^{34}$ In France, on the other hand, the institutional power of the Académie makes it hard to speak meaningfully of autonomous painting before the Salon des refusés (1863, the birthplace of impressionism) and the Salon des indépendants (1884). ${ }^{35}$ Moreover, there are many kinds of artist-patron relationship along a continuum from control by the Church or the state at one end and, at the other, a completely free market, and this often makes it difficult to establish how 'autonomous' an artist actually is or was.$^{36}$

And yet, nineteenth-century literary life in Paris and musical life in Vienna saw important shifts in the social situation of art and the artist. Paris was the cradle of artistic 'bohemia' - the city where the notion of l'art pour l'art had its most enthusiastic proponents. It was the centre of literary innovation, of new literary styles and genres, and the home of such influential poets and writers as Balzac, Hugo, and Baudelaire. Benjamin referred to Paris as the 'capital of the nineteenth century', the place where 'modern life' itself was invented.

Vienna around 1800 became the musical capital of Europe and kept this position throughout the nineteenth century. Its rich court and nobility were keenly interested in music, and attracted many composers who wanted to make a living there. It was the home of what we now call the 'First Viennese School', whose importance cannot be overestimated. ${ }^{37}$ In Vienna, as

34 See Alpers (1988). As Alpers argues, this autonomy does not only concern the free bourgeois market, but also the introduction of scenes from everyday life in painting, as contrasted with Biblical, mythological, or courtly scenes.

35 See Boime (1970) and Heinich (1996a), 35. Note that these examples only concern the Western world. Some scholars have argued that, during the Song Dynasty (960-1368), China had a free market of works of art (Hamilton (2007), 185).

36 See Williams (1995), especially Chapters 2 and 3.

37 The name 'First Viennese School', referring to Wolfgang Amadeus Mozart, Joseph Haydn and Ludwig van Beethoven (and sometimes also Franz Schubert) has been given in retrospect, 
I will show, not only did the character of music itself change, but also the appreciation and social position of the composer and of music as an art form.

\subsubsection{Literary life in Paris}

Baudelaire knew the true situation of the man of letters: he goes to the marketplace as a flâneur, supposedly to take a look at it

but in reality to find a buyer. - Walter Benjamin, 'On Some Motifs in Baudelaire ${ }^{38}$

Nowhere was the rise of the middle class felt more deeply than in France. The revolution of 1789 and the proclamation of the First Republic in 1791 marked the end of the absolute power of the Ancien Régime. In the course of the nineteenth century the 'third estate' or bourgeoisie became the dominant class, politically as well as culturally. This shift in the structure of society has a tremendous impact on the arts, which up until then could count on the nobility for protection. In the Ancien Régime, the patronage of artists was considered a status symbol. The Sun King, Louis XIV, supported a variety of artists (for instance Racine and Corneille), who received royal honours and lodging in Versailles. Contrary to what is often thought, patronage did not necessarily entail subordination. These artists often had considerable freedom to produce as they pleased. That said, to a certain extent they had to take into account the tastes of their patron, and this taste was generally theirs as well, since it reflected what was traditionally considered to be good art. César Graña writes:

What made aristocratic literature 'aristocratic' was not any one subject or aesthetic. It was rather the capacity of this literature to reflect a milieu which, by putting intellectual craftsmanship under the protection of traditional power, allowed the perpetuation of certain concerns of taste and imagination. ${ }^{39}$

This protection by patrons, along with the standards of taste patron and artist shared, starts to change once the bourgeoisie seized power. While

and only after the rise of the 'Second Viennese School' (whose best-known members are Arnold Schoenberg, Alban Berg and Anton Webern). The first 'School', however, was never a school in the sense of the second, which had a common project and teacher (Schoenberg).

$38 \mathrm{SW}_{4}, 17 ; \mathrm{I} / 2,536$.

39 Graña (1964), 38. There is also an aristocratic theory of art, namely the (Platonic) idea that art allows us to see things as they truly are. A discussion of this theory, however, falls outside the scope of this chapter (but see Heinich (1996a)). 
Napoleon still protected some artists (most notably the painter JacquesLouis David), the installation of the so-called July Monarchy after the revolution of 1830 ushered in difficult times for the artists. The popular and liberal roi bourgeois Louis-Philippe was not that interested in art. He wanted to be the 'King of the French' rather than the 'King of France' - a people's king, in other words - and he considered art an exorbitant luxury that would only obstruct this goal..$^{0}$

The dwindling level of aristocratic patronage meant that artists had to look for new ways to make a living, and for new audiences. They fund them in the ever-growing crowd of new middle-class readers: an anonymous patronage of the market. As Jerrold Seigel writes: 'For artists and writers, the basic change is as easily summarized as it was often noticed: patronage gave way to the market. ${ }^{41}$ The collapse of the Ancien Régime caused major changes in the production, distribution, and reception of literature. During Louis XVI's reign, only 36 printing houses were allowed in France. Books were luxury products, purchased almost exclusively by the aristocracy. The number of copies hardly ever exceeded a thousand, and only bibles and almanacs were printed and sold on a larger scale. Of course, industrialization contributed to the increase in production. While the traditional wooden hand press could print about 250 sheets per hour, by 1834 the iron, steam-driven mechanical press could manage 3,60o sheets per hour. ${ }^{42}$ Technological, economic and demographic factors turned publishing into an industry. In 1814, 3,000 new titles appeared; 50 years later this number had increased to almost $14,000 .^{43}$

Newspapers, too, became increasingly popular. In Paris alone, the number of daily newspapers grew from 11 in 1811 to 26 in $1846 .{ }^{44}$ During the first decades of the nineteenth century, however, newspapers were sold only by subscription, and were not generally affordable. In 1836 , Emile de Girardin, publisher of the newspaper La Presse, started a trend by lowering the price of a subscription from 80 to 40 francs, drawing the rest of his income from advertisements. Other publishers soon followed, and in France as a whole the number of subscriptions grew from 47,000 in 1824 to 70,000 in 1836 and to 200,000 in 1846 (SW 4,$13 ; \mathrm{I} / 2,528)$.

40 See Boime (1970) and Seigel (1986), 13.

41 Seigel (1986) 13. Seigel focuses primarily on the social status of writers. For the case of painting see also White and White (1965).

42 Bell-Villada (1996), 42.

43 Allen (1991), 33.

44 Graña (1964), 32. 
The impact that these changes had on literary life in Paris can hardly be overestimated..$^{45}$ The publishing industry and the newspapers created a market for literature, and most notably for the roman feuilleton. The feuilleton is a kind of cultural supplement, containing gossip, criticism, fashion news, and short stories, which are often inspired by the news of the day. Around the middle of the nineteenth-century, newspapers started publishing novels, too - a short section every day, often containing a cliffhanger at the end. Full of incident and adventure, these serial novels attracted new subscribers to the newspapers, and the roman feuilleton became extremely popular. Eugène Sue, for instance, writer of the serial novel The Mysteries of Paris (1842-1843), received a letter from a friend saying:

Your work is everywhere - on the worker's bench, on the merchant's counter, on the little lady's divan, on the shop-girl's table, on the officeworker's and magistrate's desk. I am sure that of the entire population in Paris, only those people who cannot read do not know of your work. ${ }^{46}$

The writer and critic Théophile Gautier wrote that even the illiterate would buy Sue's novel and have it read to them, and that the sick would delay their deaths in order to finish it.

Consequently, the financial situation of many serial novelists was strong. Sue, for instance, received an advance of a 100,000 francs for The Mysteries of Paris. Newspapers paid well, sometimes up to 2 francs per line (which explains why long dialogues were introduced), so business was booming for productive authors such as Sue, George Sand and Alexandre Dumas. ${ }^{47}$ The publishers usually got value for their money: after the newspaper $L e$ Constitionell contracted Sue, circulation increased from 3,000 to 40,000, while Le Siècle gained 100,000 subscribers by publishing one of Dumas's novels. ${ }^{48}$ Literature had become big business.

The democratization and commodification of literature were accompanied by utopian visions and exalted declarations reminiscent of Schiller's

45 The most vivid illustration of the impact of journalism on literary life remains Honoré de Balzac's Lost Illusions (1837-1843). Its protagonist is a provincial and naïve adolescent who travels to Paris in order to become a famous novelist, but soon falls prey to the world of journalism and the publishing industry.

46 Quoted in Allen (1991), 55.

47 Of Dumas, writer of famous serial novels such as The Three Musketeers and The Count of Monte Cristo, it was rumoured that he owed his productivity to an army of poor writers he kept locked in his basement (I/2, 532 and Allen (1991), 35).

48 Graña (1964), 34. 
(see page 30 above). In 1832 the magazine L'Artiste published the following statement:

Today the artist is placed in the middle of society as a whole, he takes inspiration from the desires and sufferings of everyone, he speaks to all, he cries for all; he is no longer a retainer but a part of the people; he expects to be paid only for his work and the free products of his genius. His social position has therefore become more moral, more independent, more able to favour the progress of art. ${ }^{49}$

On this view, in other words, the public would from now on decide the author's fate. It soon became clear, however, that the market was not kind to everybody, and many writers found themselves unable to profit from it. For every success story of a Sue or a Dumas, there were plenty of starving artists in literary bohemia, centred in the Latin Quarter of Paris and famously portrayed by Henry Murger in his Scenes from the Bohemian Life (1845-46). Bohemia, which according to Murger was the 'short road to the morgue', might be considered the first subculture in modernity. The literary market caused, in the words of Pierre Bourdieu, 'the inflow of a substantial population of young people without fortunes, issuing from the middle or popular classes of the capital and especially the provinces, who come to Paris trying for careers as writers and artists..$^{50}$ In his classic study Bohemian Paris (1986), Jerrold Seigel characterizes this artistic reserve army as both a part of and an antipode to the bourgeoisie. The bohemians shared the bourgeois values of freedom, equality, and fraternity, but considered newly emerging forms of exploitation and alienation to be a sign of the bourgeoisie's betrayal of these values. The bohemian lifestyle, which involved, among other things, a romanticization and dramatization of social and economic maladies (poverty, crime, and prostitution), was the expression of the ambivalence lying at the very heart of the bourgeois..$^{1}$

Surely not every poet was condemned to bohemia. Some, such as Stendhal and Flaubert, lived off an inheritance, while others, such as the Parnassian poets, were supported by a niche market of aristocrats and upper-class bourgeois, whom they meet in literary circles and salons. Nevertheless, it is evident that high literary quality was in itself no guarantee of popular success. There was no longer a self-evident common tradition and shared 
taste between author and public. More often their interests even ran counter to one another. In the second half of the nineteenth century, the literary elite considered popular success, in the words of the poet Leconte de Lisle, 'the mark of intellectual inferiority'. ${ }^{2}$

In this milieu, the theories of Moritz, Kant, and Schiller found fertile ground. Émigrés such as Madame de Staël and Benjamin Constant introduced their theories to the French public. Their reports, however, were based on hearsay rather than on close scrutiny. Kant's Critique ofJudgment, which was not translated into French until 1846, was therefore reduced to a set of phrases. ${ }^{53}$ Nevertheless, this misunderstanding of German aesthetics spawned the most important doctrine of nineteenth-century French literature, namely that of l'art pour l'art (art for art's sake). Théophile Gautier's preface to Mademoiselle Maupin (1835) is often considered to be a manifesto for this doctrine. He writes:

The useless alone is truly beautiful; everything useful is ugly, since it is the expression of a need, and man's needs are, like his pitiful, infirm nature, ignoble and disgusting. - The most useful place in the house is the latrines. ${ }^{54}$

The idea that an artwork is produced with no other goal than art itself appealed to many a poet, especially to those disillusioned by the market, or by the failed revolution of 1848 . Authors such as Flaubert, Leconte de Lisle, and later Verlaine, Rimbaud and Mallarmé, distanced themselves both from literature reflecting bourgeois values and from so called 'socialist' art, which, taking its cue from Hugo, portrayed the suffering of the lower classes. ${ }^{55}$ Despite their vast differences, these writers shared a contempt for public taste and for any external purpose the work of art was supposed to serve, whether this was commercial or political or propounded bourgeois morality. By the 1870 s, the doctrine of art for art's sake was so well known that Flaubert could include it in his Dictionary of Accepted Ideas: 'Artists. All charlatans. Praise their disinterestedness. ${ }^{56}$

Apart from the idea of disinterestedness, the Romantic notion of the 'genius' dominated the self-image of the nineteenth-century artist. While,

52 Quoted in Bourdieu (1996), 83.

53 See Bell-Villada (1996), 35-36.

54 Gautier in: Harrison and Wood (eds., 1992), 99.

55 Bourdieu (1996), 71.

56 Flaubert (1954), 16. 
roughly stated, the criterion for quality had lain in the extent to which the rules of good taste were followed, a new paradigm emerged in which the greatness of the artist was expressed rather by the extent to which they broke the rules. The 'new', the 'strange', the 'original', and the 'abnormal' become the new artistic values. ${ }^{57}$ The image of the artist, including the image that artists had of themselves, entered the 'regime of singularity', as Heinich calls it.$^{8}$ The notion of artistic genius reflected artists' ambivalence towards the public. On the one hand they regarded themselves as spokespersons for the truth, and therefore as representatives of 'real' humanity. They believed that through their art they pointed the way - they were part of the avant-garde of society. ${ }^{59}$ However, their message often went unheard and they were not recognized as the prophets they thought themselves to be. Consequently, the genius felt alienated from the crowd - an unsung hero. This alienation was expressed, for instance, in Baudelaire's poem 'The Albatross'. The albatross in this poem becomes an allegory for the poet, gracefully floating through the sky, but moving clumsily on deck when sailors catch it:

The Poet is a kinsman in the clouds

Who scoffs at archers, loves a stormy day;

But on the ground, among the hooting crowds,

He cannot walk, his wings are in the way. ${ }^{60}$

The poet and critic Charles Baudelaire epitomized the poet's ambivalence in nineteenth-century France. All the contradictions of the era were combined in his person and in his work: revolutionary and proponent of pure art who both praised and scorned the bourgeoisie, he was a poet of classic beauty and profane vulgarity, an unwilling bohemian and a wannabe dandy.

57 See Laermans (2009), 132-133.

$5^{8}$ Heinich (1996a), Chapter 3 . For painting, the definitive shift from academism to singularity is marked by Van Gogh, as Heinich argues in her case study: 'The new Vangoghian paradigm quite literally embodies a series of shifts in artistic value, from work to man, from normality to abnormality, from conformity to rarity, from success to incomprehension, and, finally, from (spatialized) present to (temporalized) posterity. These are, in sum, the principal characteristics of the order of singularity in which the art world is henceforth ensconced' (Heinich (1996b), 146). 59 The utopian socialist Claude Henri de Saint-Simon first uses the military term avant-garde in connection to artists: 'It is we, the artists, who will serve you as an avant-garde: the power of the arts is in fact most immediate and most rapid: when we wish to spread new ideas among men, we inscribe them on marble and canvas' (Quoted in Egbert (1970), 121).

6 o Baudelaire (1993), 17. 
To most of his contemporaries, Baudelaire was known rather as a literary and art critic and translator of English literature (Poe and De Quincey) than as a poet. He could never live off his poetry, and was himself well aware of this. In an 1846 essay entitled 'Advice to Young Authors' - full of advice he himself hardly followed - he wrote: 'In our day, it is necessary to produce quantities; therefore, one has to go fast; one therefore has to hasten slowly. ${ }^{161}$ Baudelaire seems to be acutely aware, more than any other author of his day, of the opportunities and constraints the new market situation brought along. His eulogy on the bourgeoisie in 'The Salon of 1846 ' was not meant purely ironically: 'And so it is to you, bourgeois, that this book is naturally dedicated; for any book that does not appeal to the majority, in numbers and intelligence, is a stupid book. ${ }^{62}$ These remarks, however, contrast sharply with a prose poem he wrote 20 years later, 'The Dog and the Scent Bottle' from Paris Spleen (1869), in which he presents a bottle of exquisite perfume to a dog, who sniffs and then barks disappointedly. The poet exclaims:

Ah, you wretched dog, had I offered you a bag of excrement, you would have opened your nostrils in pure pleasure, and even eaten it. You, shabby companion of my sad life, are exactly like the populace, to whom delicate fragrances, which it finds exasperating, should never be proffered, but only carefully chosen muck. ${ }^{63}$

The relation of the poet to the crowd was, to say the least, a problematic one.

Baudelaire, like so many artists, had been enthusiastic about the Revolution of 1848 , even fighting on the barricades, but he was 'physically apoliticized', as he put it, by the coup d'état of Louis Napoleon in $1851 .{ }^{64} \mathrm{He}$ became the greatest enemy of a 'committed' literature that expressed and educated bourgeois morality, especially of the so-called 'school of good sense' of Émile Augier. ${ }^{65}$ His struggle with bourgeois values reached its climax in 1857, when a lawsuit against The Flowers of Evil cost him his access not only to the public (when the book was pulled from the shelves) but also to the salons.

Despite his contempt for explicitly moral literature, Baudelaire was no proponent of l'art pour l'art either. In an introduction to the poems of his

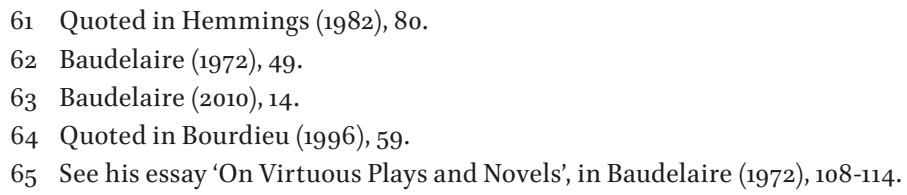


friend Pierre Dupont, he wrote: 'The puerile utopia of the school of l'art pour l'art excluded morality and often even passion, and this necessarily made it sterile' (quoted in SW 4, 12; I/2, 527). Art, he thought, should not be locked up within the confines of pure form. He wrote that, while Gautier had his friendship and his greatest admiration, his literature ran the danger 'of losing contact with reality' ${ }^{66}$ Furthermore, Baudelaire did not recognize himself in the exalted self-image of the Parnassians, the group of poets who had named themselves after the home of the Muses. Because of his lack of success, he knows all too well what modernity has in store for the poets.

Baudelaire foresaw the future of poetry in the prose poem 'Losing a Halo. ${ }^{67}$ In it, the narrator encounters a famous poet, barely recognizable, in a 'disreputable place' not further specified (but most likely a brothel), and expresses his surprise to find such a dignified creature ('you, the imbiber of quintessence, the consumer of ambrosia!') in such a place. The poet tells his admirer that, earlier that day, he lost his halo while dodging the heavy traffic of the streets of Paris. Instead of risking his life once more by picking the halo from the street, he has decided to make a virtue out of necessity: 'Now I can go about incognito, do bad things, descend to the lowest levels. So, as you see, here I am, just like you!' The narrator asks whether the poet is going to put up a notice so as to retrieve his halo, but the poet will hear nothing of it. He is quite content in his new situation, and gloats, furthermore, over the very thought of some second-rate poet's finding and wearing his halo: 'What if it was X, or Z? Wouldn't that be hilarious?' ${ }^{68}$

The image is clear. 'Losing a Halo' shows how the advance of modernity (captured in the image of heavy traffic) deprives art of its divine status. The market will disenchant art, as it does everything else. ${ }^{69}$ Instead of mourning over the lost halo, however, the poet in Baudelaire's story embraces the new opportunities, because he can behave like 'ordinary' people do. Poets who, like the Parnassians, go on pretending to be saints or prophets are making fools out of themselves, Baudelaire seems to be saying. The modern artist, he argues, should be a flaneur, out and about among the crowd, rather than above it: 'The crowd is his domain, just as the air is the bird's, and water

66 'Théophile Gautier', in Baudelaire (1972), 276.

67 Benjamin discusses this poem in 'On Some Motifs in Baudelaire' (SW 4, 342-343; I/2, 652-653). See also Berman (1982), 155-164.

68 Baudelaire (2010), 90.

69 Berman points out that Marx and Engels use the same metaphor the Communist Manifesto: 'The bourgeoisie has stripped of its halo every activity hitherto honored and looked up to with reverent awe. It has transformed the doctor, the lawyer, the priest, the poet, the man of science, into its paid wage-laborers' (quoted in Berman $(1982), 157)$. 
that of the fish. ${ }^{7^{70}}$ Baudelaire valued Constantin Guys's paintings of modern life, and he strove for something similar in his poetry, by juxtaposing the poetic and the prosaic, the exceptional and the ordinary, the exalted and the vulgar. ${ }^{71}$

For Baudelaire, contrary to what Marshall Berman argues, becoming 'ordinary' has nothing to do with becoming more 'authentic. ${ }^{2}$ Authenticity, the equation of art with genuine feeling, is what Baudelaire resents in the literature of both bohemians and bourgeois alike. For him, the 'ordinary man' is just another role the poet could play, in a society in which, as Flaubert once wrote, everything was false. In his journal, he writes: 'On the vaporization and the centralization of the Self. Everything is there. ${ }^{73}$ This conviction is behind his eulogy to make-up and fashion, as well as his contempt for the 'naturalness' of women: 'Woman is natural, that is to say abominable. ${ }^{74}$ The essential characteristic of the modern poet was, according to Baudelaire, not authenticity but inauthenticity, namely the ability to dissolving the self and relate to any member of the public, any potential buyer.

The game of identities connects the poet to the prostitute. As T. J. Clark writes in his classic study of Manet, the nineteenth-century Parisian prostitute could take on any role: 'Bored chatelaine, misunderstood bourgeoise, failed actress, corrupted peasant girl, she is all of these... She is the perpetually undeciphered enigma, intriguing and terrifying man. ${ }^{75}$ In his essays, as well as in his poems, Baudelaire repeatedly expresses his sympathy for the prostitute, and the resemblance of her fate to that of the poet..$^{76}$ Both are, as Benjamin writes, salesperson and commodity in one (AP, $10 ; \mathrm{V} / 1,55) .^{77}$

70 'The Painter of Modern Life', in Baudelaire (1972), 399.

71 See also Baudelaire's famous definition of modernity as 'the transient, the fleeting, the contingent; it is one half of art, the other being the eternal and immovable' (Baudelaire (1972), 403).

72 'One of the paradoxes of modernity, as Baudelaire sees it here, is that its poets will become more deeply and authentically poetic by becoming more like ordinary man' (Berman (1982), 160).

73 Quoted in Seigel (1986), 114.

74 Quoted in Hemmings (1982), 100.

75 Clark (1984), 111. As Clark argues, the scandal caused by the exhibition of Manet's Olympia was not because Olympia was a prostitute - prostitutes often modelled for painters - but rather because she (like Manet) obviously made no effort to mask her social class. The reason for the scandal was 'the degree to which she did not take part in the game of prostitution, and the extent to which she indicated the place of that game in class' (Clark (1984), 146).

76 See for instance 'The Venal Muse' (in: Baudelaire (1993), 27).

77 Benjamin's reflections on the relation between the autonomous work of art and the commodity will be discussed in the next chapter. 
From courtier to prophet to salesman to prostitute - such was the trajectory the poet had covered during the nineteenth century, according to Baudelaire. Although few of his contemporaries shared his realism, many shared his sense of disillusionment. Many artists had big political dreams, inspired by Fourier and Saint-Simon, and many were, like Baudelaire, disappointed by the failure of the revolution of $1848 .^{78}$ Although most of them subsequently refrain from politics, they maintain that artists are capable of disrupting common social patterns, experimenting with new forms, and exploring the unknown, thus attempting to change human consciousness. In this way, as even Baudelaire writes, 'any poem, any work of art, well made, suggests naturally and inevitably a moral. ${ }^{79}$ The critical impulse of much nineteenth-century literature, from the bohemians to Gautier and Baudelaire, is the rejection of the bourgeois principle of utility. Two souls live in the bourgeois' chest: both the lover of eternal and exalted beauty, and the 'philistine', judging art by its use - its moral, political or pedagogical value. The authors discussed here did not renounce morality or politics altogether, even after 1851 . They merely renounce the morality and politics of dominant bourgeois culture. This anti-bourgeois attitude would later be at the heart of twentieth-century avant-garde movements.

\subsubsection{Musical life in Vienna}

First Beethoven dared to compose as he wanted. - Theodor W. Adorno, Beethoven. Philosophie der Musik ${ }^{80}$

Throughout the nineteenth century, most composers remained dependent on patronage. ${ }^{81}$ Apart from some opera composers, few could live exclusively off the market - most also had a position as a teacher, a conductor, or a performer. Even today there are few composers of 'serious' music who can make a living from their compositions, without subsidies, government support and the like. Nevertheless, the nineteenth century witnessed an important shift in the social position and status of the composer: from employee and artisan to independent artist and genius - a shift from the

\footnotetext{
78 Egbert (1970), 145-163.

79 Baudelaire (1972), 20.

80 ANS 1,51 .

81 As Adorno writes in the Introduction to the Sociology of Music (1962): 'Of the famous composers of the official musical culture, the first to make full capitalist use of their production were probably Puccini and Richard Strauss' (ISM, 58; 14, 240).
} 
'professional' to the 'vocational' regime, to use Heinich's terms. ${ }^{82}$ Comparing the careers of Mozart and Beethoven, we can clearly recognize this shift.

In his youth, Wolfgang Amadeus Mozart had tasted the life of a (relatively) independent artist, travelling through Europe with his father and sister as a famous child prodigy. He had performed for, and dined with, kings and emperors. He even sat on the Empress's lap in Vienna, and kissed her cheek. He had lived more or less on an equal footing with the aristocracy, and he felt that he deserved no less for his talents, of which he was very conscious.

One can imagine, then, his discontent when he became court musician to Archbishop Colloredo in Salzburg - a subordinate position. Composers in service of a court were regarded, and treated, as common employees. During a visit by Colloredo to Vienna, Mozart complained in letters to his father that he had been treated as the archbishop's doormat, dining with the lackeys, and forbidden to take on any other commissions. Soon Mozart could no longer acquiesce in what he saw as this servile role, and offered his resignation to the archbishop. In a letter to his father, who vehemently protested his decision, he reassured him that he would be able to live off several commissions: 'I would rather go out begging than ever to serve such a master again. ${ }^{83}$ After much nagging from Mozart's side, Colloredo agreed to his resignation, after which Mozart was literally kicked out of the archbishop's house by the chamberlain. ${ }^{84}$

Vienna at the end of the eighteenth century was the economic and cultural centre of the Habsburg Empire, and the seat of the throne. Mozart set his hopes on the good graces of Joseph II, but also envisaged himself as an independent artist, selling his compositions to publishers and organizing subscription concerts. Traditionally, concerts were courtly events, with an audience of invited guests. Subscription concerts, by contrast, were open to anyone who paid in advance, and the proceeds went to the composer and the musicians. At first Mozart was quite successful. He received commissions from the Emperor, while his subscription concerts were popular, as he proudly wrote to his father. ${ }^{85}$ This success did not last, however. In 1789, a series of concerts had to be cancelled because there was only one subscriber (namely his friend and protector baron Van Swieten).

The problems Mozart ran into in his struggle to be an independent artist were twofold. First, the lack of copyright protection made it impossible for 
him to earn money through the printing of his work. A composer could sell his compositions to a publisher only once, and no one could prevent other publishing houses from printing pirate copies afterwards. The second problem he encountered was the lack of a middle-class audience. Although Mozart wanted to be independent from any (aristocratic) employer, the audience he sought would still consist mostly of aristocrats. Mozart knew this, of course, but he misjudged the extent to which the Viennese aristocracy would be able to appreciate his musical experiments. His later compositions were often considered too difficult. ${ }^{86}$ The chilly reception that greeted The Marriage of Figaro in 1786 marked a turning point in the Viennese appreciation of Mozart. The opera was considered too critical of the social structure, and the aristocratic audience turned its back on him, making it ever harder for him to make a living. The (by no means completely fictitious) destitution of his last years was partly a result of his own extravagance, but can also be traced to his keenness to enter a market that did not yet exist. ${ }^{87}$

Shortly after Mozart's death in 1791, the social status of the composer changed drastically, as can be seen from the case of Ludwig van Beethoven, who was born only 15 years later than Mozart. Beethoven's relationship with his employer, Elector Maximilian Franz of Bonn, differed greatly from Mozart's with Colloredo. Maximilian Franz allowed Beethoven to travel freely, and paid for the lessons he took from Salieri and Haydn. Only after he had already spent 2 years in Vienna did the Elector decide to cut off his salary. After 1794 Beethoven would never again have an official appointment. By then copyrights were better regulated, and Beethoven had the luxury of seeing publishing houses fight over his compositions. In 1800 he wrote:

My compositions bring in a considerable amount, and I might say that I have more commissions than I can possibly honor. I can also count on six or seven publishers for each thing, and even more, should I want them. People no longer bargain with me; I demand and they pay. You can see that this is a rather nice situation. ${ }^{88}$

Beethoven is often said to be the first genuinely independent composer. We should, however, not take the epithet 'independent' too literally. Besides a

86 According to a famous anecdote, Emperor Joseph II commented on The Abduction from the Seraglio: 'Zu schön für unsere Ohren, und gewaltig viel Noten, lieber Mozart.'

87 See also Elias (2010).

88 Quoted in Wegeler and Ries (1987), 28. Lewis Lockwood writes: 'He was [...] the first major composer whose music was regularly printed during his lifetime by a host of publishers, sometimes in rival editions' (Lockwood (2003), 88). 
few compositions, such as Wellington's Victory, Beethoven's work did not attract a mass middle class audience during his lifetime, and the major part of his income was still provided by the aristocracy. It would thus be a gross exaggeration to say that Beethoven single-handedly overthrew the patronage system. ${ }^{89}$ Nevertheless, the relation between him and his patrons was no longer one of employee to employer, but was based on equality and reciprocity. Aristocrats would pay him for nothing but his friendship, which in turn granted them the status of supporting a famous 'genius'.

How radical and sudden this shift was, is nicely illustrated in the memoires of Frau von Bernhard, a friend of the aristocratic family Lichnowsky, one of Beethoven's patrons:

I still remember clearly Haydn and Salieri sitting on a sofa, both carefully dressed in the old-fashioned way with wig, shoes, and silk stockings, while Beethoven would come dressed in the informal fashion of the other side of the Rhine, almost badly dressed. I myself saw the mother of Princess Lichnowsky, Countess Thun, go down on her knees to him as he lolled on the sofa, begging him to play something. But Beethoven did not... ${ }^{90}$

Clearly, the tables had turned. To be sure, Beethoven stays on good terms with the aristocracy, but only as long as it is of service to him. Anyone who dares to interfere with his work has to pay the price of antagonism..$^{91}$

When, in 1809, Beethoven considered taking on the function of Hoffkapellmeister in Kassel, three Viennese aristocrats whom he had befriended offered him an annual payment of a thousand florins. They asked him, in return, only to remain in Vienna. A contract they drew up read, in part:

As it is fairly clear that one needs to be free of worries to fully dedicate oneself to a cause and create grand and outstanding works, the signatories have decided to enable Mister Ludwig van Beethoven to fulfil his most relevant necessities in order to not inhibit his powerful genius..$^{92}$

89 See DeNora (1995), 38.

90 Quoted in Lockwood (2003), 78.

91 There is a famous and probably not completely fictitious anecdote about a conflict of Beethoven with his patron prince Lichnowsky. In a letter to the prince Beethoven writes: 'Prince! What you are, you are through chance and birth. What I am, I am through myself. There have been, and will be thousands of princes. There is only one Beethoven!' (quoted in: Cooper (ed., 1991), 104).

92 Quoted in Cooper (ed., 1991), 69. 
The text of this contract offers an insight into the status, not only of the composer, but also of music. Until the end of the eighteenth century, music was not considered an 'autonomous' art form or as an end in itself. It functioned as an accompaniment to religious services, courtly festivals, meals, military marches, or, in the case of the opera, as a form of entertainment. ${ }^{93}$ In the course of Beethoven's life, and partly thanks to him, music began to be seen, as Lockwood writes, 'not as a marvellous craft but as an inborn, basic means of human expression. ${ }^{94}$ In contrast with the works of Bach, Händel, Haydn, and Mozart, Beethoven's most important works were instrumental - the sonatas, quartets, and symphonies - that served no other purpose than music itself. For the first time, these works were granted the status of works of art.

In the nineteenth century, and especially in the German-speaking countries, music became the juggernaut in the aforementioned battle between Kultur versus Zivilisation. The aristocracy considered music as a form of entertainment. An aristocrat visiting an opera usually showed up at the end of the first act, talked during the second, and left during the third. For the nineteenth-century bourgeois, by contrast, music represented the nobility of the soul, and was to be revered as such. They not only disapproved of the aristocratic attitude, but also of the vaudeville theatres of the lower classes, where arias by Rossini and Mozart alternated with popular songs and other 'vulgarities'. Consequently, a new etiquette was introduced to the music theatres. Doors were locked once the music started, food and drinks were no longer allowed in the hall, the lights were dimmed during the concert, silence was required and it was considered rude, even barbaric, to leave early. ${ }^{95}$ This 'sacralization' of music brought with it a division between serious music as 'high art' on the one hand, and vaudeville and variety theatre as 'low art' on the other..$^{96}$

Along with the rising status of the composer, and the sacralization of the music, the nineteenth century witnesses the birth of a theory of musical

93 DeNora (1995), 16.

94 Lockwood (2003), 171.

95 See Smithuijsen (2001), 88-99. As Smithuijsen writes, Richard Wagner's Festspielhaus in Bayreuth, which opened in 1872 , contained many architectural novelties, functioning to focus the audience's attention solely on the stage.

96 Of course, this goes not only for music, but for all of the arts. Lawrence Levine writes: 'No more than drama, opera, or instrumental music, then, were painting and sculpture elevated above other forms of expressive culture in the first half of the nineteenth century; they were part of the general culture and were experienced in the midst of a broad range of other cultural genres by a catholic audience that cut through class and social lines. This situation began to change after mid-century and, characteristically, the change was accompanied by sacred language and religious analogies' (Levine (1988), 149). 
autonomy. According to both Rousseau and Kant, music was still inferior to the other fine arts, since it stimulated merely the senses and not the intellect. The latter wrote: '[Music] is admittedly more a matter of enjoyment than of culture [...] and in reason's judgment it has less value than any other of the fine arts. ${ }^{\prime 97}$ Still, it is Kant's own theory of the sublime (which he himself restricts to nature) that provides music critics of the nineteenth century with a new vocabulary. The sublime, as both Kant and Edmund Burke described it, is the experience of something infinitely great or powerful, which would arouse a feeling of terror in the subject, but that tey can still enjoy, knowing they are safe. This is clearly what E. T. A. Hoffmann had in mind in 1810, when he wrote that Beethoven's Fifth Symphony:

opens the realm of the colossal and the immeasurable for us. Radiant beams shoot through the deep night of this region, and we become aware of gigantic shadows which, rocking back and forth, close in on us and destroy all within us except the pain of endless longing [...]. Beethoven's music evokes terror, fright, horror, and pain, and awakens that endless longing that is the essence of romanticism..$^{8}$

Arthur Schopenhauer, differed from both Kant and Hegel in seeing music as standing at the top of the hierarchy of art forms, and precisely because it does not represent specific ideas, as the other art forms do. Music speaks directly to us, he argued in The World as Will and Representation (1819), without the mediation of images, concepts, or ideas, and therefore it can express the very essence of the cosmos: '[Music] never expresses the phenomenon, but only the inner nature, the in-itself, of every phenomenon. ${ }^{99}$ Consequently, Schopenhauer disapproved of Tonmalerei, or any other way of mimicking nature through tones, and considered instrumental music superior to vocal. ${ }^{100}$ Lyrics, he argued, are at best aesthetically irrelevant, and at worst distract us from the pure meaning of music by focusing our attention on arbitrary details.

The mimetic discourse of music, that is, the idea that music mimics sounds or represents emotions, receives another blow from the Viennese

97 Kant (1987), 328: 189 .

98 Quoted in Lockwood (2003), 220.

99 Schopenhauer (1959), vol. 1, 261.

100 See his Paralipomena: 'The great opera is, really, not a proof of a pure sense for the artistic, but rather of the somewhat barbaric notion of raising aesthetic pleasure through the accumulation of means, the simultaneity of completely different impressions, and the strengthening of effect through the increase of working masses and forces; whereas music, of all the arts the most powerful, should perfectly space out the susceptible mind' (Schopenhauer (1986), II, 509). 
music critic and theorist Eduard Hanslick. In his seminal essay, Of the Musically Beautiful (1854), he argues that the essence of music cannot have anything to do with human emotions. Arousing emotions, in his view, is not music's function, and emotions are not its content. Just as we cannot learn the essence of wine by getting drunk, we will not, he argues, learn about music by getting emotional. Furthermore, the emotions we attribute to music are mere human projection - music may be restless or tranquil, but the association with the restlessness or tranquillity of the heart has nothing to do with it. In the spirit of Kant, Hanslick writes: 'In pure contemplation the hearer takes in nothing but the piece of music being played; every interest must be far from him. One of those is the interest to arouse affects in him. ${ }^{101}$ In what seems to be a tautology, Hanslick states that the true nature of music is musical, and that the only things expressed in it are musical ideas. ${ }^{102}$ Its language has syntax, but no semantics - like formal logic - and can therefore not be translated to any other language. And yet, musical ideas are not empty, but rather filled with the creativity of the human 'spirit'. Since in Hanslick's theory music refers to nothing but its own formal laws, it has been called a theory of 'absolute music.. ${ }^{103}$

What do we learn from this juxtaposition of musical, cultural, economic and theoretical developments? First, we have seen the shift, exemplified in the careers of Mozart and Beethoven, in how composers were regarded: from craftsman and servant to genius and master. Second, his went along with the institutionalization of the bourgeois idea of a separate cultural sphere. Music, instead of having to fulfil an immediate function, was increasingly regarded as a goal in itself, and, for that very reason, as the gateway to the sublime, the divine, or the 'absolute'. This 'autonomization' of music in turn provided the composer with the freedom to experiment with the laws and techniques of the art form.

However, Schopenhauer's and Hanslick's theories of absolute music reflected an ambivalence towards its place in bourgeois society. While they shared with the bourgeoisie the idea of a separate cultural sphere, autonomous from other spheres in society, their theories also resisted granting new functions to music, especially that of entertainment. They opposed not only the commodification of music that necessarily underlay its autonomy, but also, as can be seen most clearly in Hanslick's essay, the idea of music as an emotional stimulant. The general public, he argued,

101 Hanslick (1990), 29.

102 Ibidem.

103 Or, as musicologist Peter Kivy calls it, 'music alone'. See Kivy (2002), 25. 
turned to music in order to arouse a range of common-of-garden emotions or to be in contact with the divine, thus misunderstanding music's true nature and jeopardizing its true autonomy.

In The Philosophy of New Music, Adorno wrote: 'Since the middle of the nineteenth century, great music has broken away from social functionality of any kind. The logic of its development now stands in conflict with the manipulated and simultaneously self-content needs of the bourgeois public' (PNM, 11; 12, 17). In the production, as well as in the justification, of music during the second half of the nineteenth century (and, as we will see below, in the first half of the twentieth), one can recognize an increasing hostility towards the public, resulting in music that is unintelligible to laypeople.

\subsubsection{Autonomy and resignation}

The idea of art as autonomous - disinterested, having no function in society, detached from morality, pedagogy and politics, and existing for nothing but itself - is rooted in the actual social, cultural and economic autonomy of the artist and of art as an institution. Art emancipates itself from church and court, and becomes an autonomous subsystem in bourgeois society. With the decline of patronage, art entered the free market. Paradoxically, therefore, art becomes autonomous the very moment it becomes a commodity. The idea of art as autonomous - as found in l'art pour l'art as a movement and in the theories of absolute music - can be understood as a response to its commodification. As Bourdieu argues, the economic logic of art industries is complemented by 'an anti-"economic" economy of pure art'. ${ }^{104}$ Commercial, popular and 'lowbrow' entertainment stands in contrast to pure, avant-garde and 'highbrow' art.

In his Theory of the Avant-Garde (1984[74]), Peter Bürger states that the category of autonomous art belongs to bourgeois society. The fact that the theories of autonomous art reflect the autonomy of art as a socio-historical phenomenon marks their 'truth moment'. However, as Bürger further argues, these theories also have an ideological moment, insofar as they

104 "At one pole, there is the anti-"economic" economy of pure art. Founded on the obligatory recognition of the values of disinterestedness and on the denegation of the "economy" (of the "commercial") and of "economic" profit (in the short term), it privileges production and its specific necessities, the outcome of an autonomous history. [...] At the other pole, there is the "economic" logic of the literary and artistic industries which, since they make the trade in cultural goods just another trade, confer priority on distribution, on immediate and temporary success, measured for example by the print run, and which are content to adjust themselves to the pre-existing demand of a clientèle' (Bourdieu (1996), 142). 
fail to recognize the specific historical origins of the autonomy of art, and posit it as an absolute truth: "The category "autonomy" does not permit the understanding of its referent as one that developed historically. ${ }^{105}$ In other words: the artists embracing the doctrine of l'art pour l'art or the theories of absolute music ignore the fact that the same bourgeois society they turn their backs on constitutes the very condition of their resignation.

Moreover, it cannot be said that the doctrine of l'art pour l'art and the theories of absolute music are completely disconnected from morality or politics. These ideas object not to functions per se, but rather to specific functions; not to morality and politics as such, but to specific forms of morality and politics. As Benjamin argues in his essay on surrealism, "art for art's sake" was scarcely ever to be taken literally; it was almost always a flag under which sailed a cargo that could not be declared because it still lacked a name' (SW 2, 211-212; II/1, 301). In other words, even for someone as radical as Gautier, art never exists solely for its own sake. It wants something, it opposes something, it takes a certain stance towards society. For certain nineteenth-century European artists, especially after 1848, art and the idea of its autonomy did indeed have a specific function, namely that of resignation from bourgeois society and politics. The idea of pure art allows artists to turn their backs on society, and to be concerned with nothing other than with the laws and techniques of the art form. Art, the realm of the beautiful, becomes the only way to escape the foul world of bourgeois society. This is probably what Flaubert meant when he equated the beautiful with the moral: that it is only possible to live a good life outside existing society, namely in the realm of artistic beauty. ${ }^{106}$

One can understand this idea of art as a 'kingdom not of this world' in a way that is similar to how Karl Marx understood religion. His famous characterization of religion as 'the opiate of the people' implies that it contains both a reactionary and a utopian moment. It is reactionary because people are made to cherish an illusion and project onto an afterlife what they really yearn for in present life. But from this it follows for Marx that religion is also an expression of an authentic utopian desire for a different society. The same can be said about the nineteenth-century notion of pure art. Artists turn their backs on a degenerate society, in a genuinely critical gesture, only to become utterly impotent - 'quite useless'. In this way, an initially critical and anti-bourgeois gesture plays into the hands of bourgeois society after 
all: since happiness and beauty are realized in the imaginary world of art, one finds oneself absolved of the duty to realize it in real life. This is what Herbert Marcuse characterizes as 'the affirmative character' of the separate cultural sphere. ${ }^{107}$ The problematic relationship between art and society was to become the single most important theme of early twentieth-century art and art theory, to which I turn in the last section of this chapter.

\subsection{Art versus society}

The anti-bourgeois sentiments of art reach a climax at the dawn of the twentieth century, which witnesses an overall feeling of alienation and pessimism among artists and intellectuals, and a shared sense of nervous anticipation of change that would bring about the self-destruction of Western bourgeois culture, which, as they saw it, had become decadent and was bound to collapse under its own weight, and whose once promising values had become pale and rotten. The Viennese poet Hugo von Hofmannsthal wrote in 1905: 'We must take leave of a world before it collapses. Many know it already, and an indefinable feeling makes poets out of many. ${ }^{{ }_{108}}$ This collapse eventually occurs in the shape of the First World War, which in the eyes of many definitively confirmed the bankruptcy of bourgeois values. It was not freedom and forbearance, or - as Kant and Hegel had envisioned - 'perpetual peace' that turned out to be the goal of Europe's bourgeois societies, but a brutal fight over power and land that cost the lives of millions. Technological progress had resulted, not in the emancipation of humanity, but in a fatal cocktail of machine guns, tanks, fighter planes and poison gas. Europe had turned into a wasteland, and the ideals of the enlightenment lay buried in the trenches.

In this crisis, the function of art once more came into question. Had art not provided a realm in which the bourgeois individual could turn their back on life, thus precipitating the alienation and atomization of society? Was art's claim to freedom and independence not simply an excuse for its impotence, and an all-too-easy escape from its responsibilities? Was beauty not in some way an accessory to these horrific events? Art had lost its natural raison d'être, and along with all the other bourgeois values, the autonomy of art had become suspect. Every artist in the first decades of the twentieth century had to somehow reckon with the problem of art's relationship to

107 In Marcuse (1968), 88-133.

108 Quoted in Schorske (1981), 8. 
society. By discussing once more Parisian literature and Viennese music, we will see how the foundations of art were stirred yet again.

\subsubsection{Paris revisited: Surrealism}

One can long argue about which of the historical avant-garde movements futurism, Dadaism, or surrealism - had the greatest impact. Futurism, with its fascination for war, destruction, and 'the machine', was soon surpassed by the passage of time, although it continued to be highly influential in the course of the history of art. Dada's nonsensical anarchism was, from the beginning, bound to have a short lifespan, and was already pronounced dead in 1922 by one of its founders, Tristan Tzara. Nevertheless, it had its revivals in movements such as Lettrism, the Situationist International, Fluxus and the neo-avant-garde, all of which drew inspiration from Dada as well as from Surrealism. Dada was also the basis for Marcel Duchamp's Fountain (1917), which is generally regarded as one of the most important works of the twentieth century. Surrealism, however, can be argued to have had the greatest lifespan as not just an artistic but also a social movement. In the first half of the twentieth century, it outlasted both futurism and Dada, and also outdid them in terms of diversity of styles, conceptual wealth, and international character.

Paris was the cradle of surrealism, but its roots lay in Zürich in neutral Switzerland, where artists of different nationalities had gathered and, on 5 February 1916, had founded the Cabaret Voltaire, a 'centre for artistic entertainment'. Dada becomes the nonsensical name of the nonsensical art performed and produced there, in forms varying from poems to plays, and from drawings to costumes. Hans Arp, who was among the first Dadaists, later wrote:

In Zürich in 1915, losing interest in the slaughterhouses of the world war, we turned to the Fine Arts. While the thunder of the batteries rumbled in the distance, we pasted, we recited, we versified, we sang with all our soul. We searched for an elementary art that would, we thought, save humankind from the furious folly of these times. ${ }^{109}$

The search for a new kind of art results in anti-art. So much is clear from the setting: a bar instead of a theatre, and 'entertainment' instead of 'high' art. The Dadaists did not aim for beauty, nor did they want their performances to have 'meaning'. They deliberately crossed the line into the realms of the 
unintelligible and nonsensical. For Richard Huelsenbeck's poem 'The Admiral is Seeking a House to Rent', for instance, three performers simultaneously chant in three different languages. Dadaist 'works' depended on spontaneity and chance. Their collages consisted of 'found objects' - train tickets, grocery lists, pieces from posters and magazines -, while their so called Wortsalat poems were made up of randomly shuffled newspaper scraps. Dadaist performances were mostly improvised, the performer saying or chanting the first thing that would come to their mind. Tzara wrote that 'the thought is made in the mouth', and argued against the bourgeois myth of the artist as the creative genius, and the work of art as their most personal and authentic expression. ${ }^{110}$

According to the Dadaists, the only antidote to the hypocrisy of bourgeois art is the banality of such anti-art. For that reason, as Bürger argued, Dada cannot be conceived of as a 'style' or 'school' in the same manner as, for example, impressionism. Dada marked, in Bürger's terms, the transition from a system-immanent critique to a self-critique, meaning that it does not merely criticize and reform a preceding style, but questions and contests the validity of the art institutions (the theatre, the museum) and the function of art in bourgeois society. ${ }^{111}$ As Huelsenbeck states:

The Dadaist considers it necessary to come out against art, because he has seen through its fraud as a moral safety valve. Perhaps this militant attitude is a last gesture of inculcated honesty, perhaps it merely amuses the Dadaist, perhaps it means nothing at all. But in any case, art (including culture, spirit, athletic club), regarded from a serious point of view, is a large-scale swindle. ${ }^{112}$

The Dadaists' contempt for art is expressed, for instance, in their behaviour towards their audiences, which they mock, shout at and scold, and which in turn treat them with hissing, booing, and throwing eggs and tomatoes.

The activities of the Dadaist movement in Zürich lasted for only a few months. In 1917 its members spread out and organized Dadaist activities in Germany, the Netherlands, and the United States. Tristan Tzara went to Paris, where he met the future founder and leader of the surrealist movement, André Breton.

In 1919, Breton, together with Phillippe Soupault and Louis Aragon, founded the literary magazine Littérature, as the Parisian platform for Dada. 
By the time Tzara arrived in Paris in 1920, however, Breton was no longer convinced of the critical force of Dada. Nonsense for the sake of nonsense, he thought, would eventually turn out to be as impotent as art for art's sake. What needed, he believed, was ideas and convictions. ${ }^{113}$

What had initially attracted Breton to Dada was its emphasis on the subconscious and the coincidental. While working with shell-shocked soldiers in the Centre Neurologique in Nantes during the war, Breton had become intrigued by the power of the subconscious. This fascination was stimulated by the work of Freud, whom he deeply admired. Breton came to believe that the only path to a radical change in the social order was through a liberation of the subconscious.

Hence, from the beginning Breton was concerned not merely with a revolution in art, but also with the functioning of the human mind. In 1919, he and Soupault experimented with 'automatic writing', the scribbling down of anything that comes to one's mind, without the intervention of conscious critical reflection. The principle underlying automatic writing was, like the Dada performances, directed against notions such as autonomy, authenticity, and genius. Breton wrote: 'We have no talent [...]. [W]e have made ourselves, in our works, the deaf receptacles of so many echoes, the modest recording devices that are not hypnotized by the designs they trace. ${ }^{114}$ The surrealists did not consider the products of these experiments as works of literature or art, but thought they were valuable to the extent that they provided new insights into the functioning of the mind. It is this non-aesthetic interest that Breton found lacking in Dada.

A public confrontation between the Dadaists and the Littérature group took place during a performance, in July 1923, of Tzara's play Coeur à gaz, which Breton and his friends came to disrupt. A fistfight broke out, Tzara called the police, and the intruders were forced to leave. This incident marked the definitive break between the Dadaists and the group surrounding Breton, which had already begun to call itself 'surrealist', after a term coined by a friend of Breton, the poet and critic Guillaume Apollinaire.

About a year later, the Bureau of Surrealist Research opened its doors at 15 rue de Grenelle. This quasi-scientific institute intended to 'gather all the information possible related to forms that might express the unconscious activity of the mind." ${ }^{\prime \prime 5}$ Advertisements encouraged everybody to enter the building and tell their secrets, their dreams, hopes and ideas. By December

113 See Seigel (1986), 374.

114 Quoted in Nadeau (1973), 97 (original italics).

115 Quoted in Durozoi (2002), 63. 
1924 the Bureau had its own journal, La Révolution surréaliste, which published drawings, photographs, dreams, poems, and automatic texts by the surrealists.

In that same year Breton published the Surrealist Manifesto, in which he formulated the concept of surrealism and its aims: the reconciliation of dream and logic, private and public, consciousness and the subconscious: 'Why should I not expect from the sign of the dream more than I expect from a degree of consciousness which is daily more acute? Can't the dream also be used in solving the fundamental questions of life?"116 According to Breton, the only way to change society was to move away from the well-worn paths in the regular sciences, which with their narrow concept of mind had neglected all aspects of human consciousness that appeared alien and hostile: the subconscious, the accidental, the primitive, the childlike, the dream. He wrote: 'I believe in the future resolution of these two states, dream and reality, which are seemingly so contradictory, into a kind of absolute reality, a surreality, if one may so speak. ${ }^{{ }^{117}}$

The manifesto gave a definition of surrealism in the form of an encyclopaedia or dictionary entry:

SURREALISM, $n$. Psychic automatism in its pure state, by which one proposes to express - verbally, by means of the written word, or in any other manner - the actual functioning of thought. Dictated by thought, in the absence of any control exercised by reason, exempt from any aesthetic or moral concern. ${ }^{118}$

Vague as this definition may be, it is remarkable that there is no mention of art or poetry. The surrealists did not consider themselves to be primarily an artistic movement. Literature, to them, was of minor importance, and on several occasions they even expressed their contempt for it. Breton repeatedly announced his intention to give up writing poetry once and for all: 'I've never strived for anything else, I repeat, than to ruin literature. Poetry? There's no poetry where we think there is. Poetry exists outside words, style, and so on, and that's why I'm delighted when I read a book that is really badly written." ${ }^{\prime 19}$

The group's contempt for literary writing is particularly aimed at the novel form - the most popular literary form by far, and, as Hegel already noted, the

116 Breton in Harrison and Wood (eds., 1992), 449.

117 Ibidem, 450.

118 Ibidem, $45^{2}$.

119 Quoted in Durozoi (2002), 54. 
bourgeois genre par excellence. Whereas courtly and religious literature necessarily contained a collective element in its production and reception (because it was embedded in festivities or ritual), the novel is produced by an individual, expresses individuality in its form, and is typically consumed in solitude. ${ }^{120}$ It is, in other words, completely detached from public life. Moreover, it satisfies the reader's need for a logical and organized structure, thus, according to the surrealists, restricting their imagination. This suspicion of the novel form went quite far: Aragon succumbed to pressure from the group to burn the manuscript of his three-volume novel Défense de l'infini, for which he had already signed a contract, and Soupault - a surrealist from the beginning - was expelled from the group in 1926 because of his literary activities. ${ }^{121}$

Although the novel form was held in contempt by the surrealists, their attitude towards literature was ambivalent. Words, Breton argued, have a life of their own: they 'command thought' and are 'creators of energy.'122 Only by liberating this energy, he thought, could literature, as an exploration of the subconscious and an instrument for revolt, hold any significance for the surrealists. In the Declaration of 27 January 1925, we read:

We have nothing to do with literature. But when necessary we are as capable as anyone else of making use of it. [...] SURREALISM is not a poetic form. It is a cry of the mind as it turns back towards itself and is determined to smash its fetters, if necessary with material hammers. ${ }^{123}$

This declaration again emphasizes the spiritual and political, rather than the artistic, aims of the group.

But what to think then of surrealist 'novels' passed down to us: Aragon's Paris Peasant (1926) and Breton's Nadja (1928), to name only the most famous ones? Although we consider these works to be novels, the surrealists certainly did not. And given the typical novel back then, there was certainly something to be said for this view. The reason why we conceive of these works as 'novels' today has much to do with the expansion of the term 'novel' by the avant-gardes.

Given the scientific ambitions of the surrealists described above, Breton's Nadja can perhaps best be understood as a 'case study': it records 'surreal'

120 Typically, Daniel Defoe's Robinson Crusoe, the story of a man stranded on a desert island, is often referred to as the first novel (see, for instance, Watt (1957)).

121 Nadeau (1973), 113 and 148.

122 Quoted in Nadeau (1973), 92.

123 In: Richardson and Fijalkowski (eds., 2001), 24. 
episodes in the life of the author, and associations in his mind. Photos and illustrations have replaced the naturalistic description one would expect in a novel. Nadja is the report of a ten-day liaison Breton had with a mentally ill woman he encounters on the streets of Paris and whom he coincidentally meets several more times. In her naïveté and non-conformism, Nadja seems to make a better surrealist than even Breton himself, as he has to confess. Finally, Nadja is a critique of modern society and the way it deals with people such as Nadja, putting them away in mental institutions instead of learning from them. Similarly, Aragon's Paris Peasant cannot be called a traditional novel, but is rather a montage. The style ranges from essay to poem and from dream protocol to philosophical treatise. Aragon wanted to write a 'modern mythology', in which Parisian city life was viewed in a radically new manner. He included found objects such as advertisement plates, street signs, and menu cards, aiming, as he himself put it, to destroy the novel by its own means. ${ }^{124}$

The surrealists valued art and literature only insofar as they were of service to a spiritual revolution and a social revolution, which they saw as mutually dependent. After 1925 the group became more explicitly political, and most members joined the French Communist Party. This did not mean that they subjected themselves to the Party's will, but merely that the goals of the surrealist group and the Communist Party ran parallel to one another for the moment. For Breton, Party membership was all the more reason to emphasize the group's independence. The Party officials, for their part, looked Argus-eyed at the surrealists, because of their refusal to follow the Party line and produce functional (that is to say propagandistic) art. In 1931, after having visited Moscow, Aragon declared that in order to become a communist, he would have had to renounce surrealism. Soon afterwards, the Communist Party declared that socialist realism was the only official communist art form, and Breton and the other remaining surrealists were expelled. ${ }^{125}$

According to Breton, the revolution in society and the revolution in the mind were mutually dependent. The value of surrealist works for the revolution, therefore, lay not in its propagandistic content but in its revolutionary form. ${ }^{126}$ This made the surrealists' stance towards the autonomy

124 See the epilogue by Hofstede in Aragon (1998), 199.

125 Nadeau (1973), Chapters 14 and 16.

126 Breton's conception of the relation of art and politics is close to that of Leon Trotsky (whom he admired and later visited in Mexico). In his essay Literature and Revolution Trotsky writes: 'As far as the political use of art is concerned, or the impossibility of allowing such use by our enemies, the party has sufficient experience, insight, decision and resource. But the actual 
of art highly ambivalent. On the one hand, they rejected the autonomy of art as a bourgeois institution, detached from life and functioning as a hideout for beauty and consolation, from which one could momentarily ignore the horrors of reality. The surrealist, by contrast, wanted to reconcile art and life, dream and action. However, as Bürger stresses, the surrealists wanted to connect art, not with actual life, with the status quo, but only with a revolutionary praxis and with a thoroughly transformed society. ${ }^{127}$ In that sense, the autonomy of art was the necessary condition of its political utilization. I shall come back to this later.

To summarize the surrealist critique of the function of art in society, we can distinguish three main points. First, the surrealists broke radically with the nineteenth-century conception of art as a divine creation and an other-worldly realm of beauty. This realm, they argued, functions as an ideologically derived defence for political resignation. Instead of soothing the public by offering them beauty, the surrealists wanted to shock and provoke it. Art, in their view, should not be detached from but connected to life, and should foreshadow a different life. Second, they argued that this revolutionary goal demanded a new mode of literary production. Automatic writing, free association, and found objects were, they thought, literary forms destined for new, collective ways of production and reception. Finally, art was for them not an end in itself. Works of art were experiments, carried out in order to document and eventually change the functioning of the human mind. As such they simultaneously functioned instrumentally within a social struggle.

\subsubsection{Vienna revisited: Arnold Schoenberg}

Fin-de-siècle Vienna was drenched in art: feuilletons in the newspapers, fancy Jugendstil decorations in upper-class bourgeoisie interiors, and a booming concert life. Art was the main status symbol, and devoting oneself to it the primary means of emphasizing one's cultural distinction. ${ }^{128}$ In $f i n$ -

development of art, and its struggle for new forms, are not part of the party's task, nor is it its concern. The party does not delegate anyone for such work' (Trotsky in Harrison and Wood (eds., 1992), 444).

127 'The praxis of life to which Aestheticism refers and which it negates is the means-ends rationality of the bourgeois everyday. Now, it is not the aim of the avant-gardistes to integrate art into this praxis. On the contrary, they assent to the aestheticists' rejection of the world and its means-ends rationality. What distinguishes them from the latter is the attempt to organize a new life praxis from the basis in art' (Bürger (1984), 49).

128 See Janik and Toulmin (1973), 44. 
de-siècle Vienna, culture was indeed, Marcuse put it, 'affirmative', affirming instead of contesting existing social relations, and veiling the political inequality, moral duplicity, and stifling social atmosphere of the Habsburg society. The taste of the bourgeoisie was conservative, seeking comfort in the classics and frowning upon the latest artistic schools and styles. This conservatism provoked the Viennese artists to adopt a militant hostility towards their public. Charles Rosen writes: 'If the pastime of shocking the bourgeois took on at times a playful aspect in Paris and London, in Vienna it was carried on with a bitter seriousness only occasionally masked by wit. [...] For the Viennese artist and musician, the public was the enemy."129

The warlords in the battle against bourgeois aestheticism, or what counted as 'good taste', were the literary critic, poet and playwright Karl Kraus and the architect Adolf Loos. Kraus, who considered Vienna the 'research station for the Apocalypse', targeted the degenerate literary style of the popular feuilletons in the Neue Freie Presse. For him, the authors of these feuilletons commit not merely an offence against literature. Since language, he argued, is the very constitutor of our thoughts, not a mere medium, the degeneration of language entails the moral degeneration of Viennese culture.

Adolf Loos, founder of a journal entitled, The Other:Journal for the Introduction of Occidental Culture in Austria, fought a similar battle against $J u$ gendstil. In his seminal essay, 'Ornament and Crime' (1908), he expressed his contempt for the bourgeois' decoration of everything - doorknobs, ashtrays, banisters, the entire interior - and he equated this over-ornamentation with tattoos worn by barbarians and criminals, and with the graffiti on lavatory walls. He also made a sharp distinction between objects of use, which were there to increase human comfort, and objects of art, which were supposed to be purposeless, disquieting, and were such that they would 'tear people from their comfort. ${ }^{130}$ Either way, in the functionality of the house or in the disturbing nature of art, beauty was to become superfluous, according to Loos.

Bourgeois conservatism dominated Vienna's musical life, too. The concert and opera houses staged popular classics, while contemporary works were seldom performed. The official music practice lives in and off the past. Although Gustav Mahler was esteemed as a conductor at the Court Opera, his own compositions were regarded as barely excusable eccentricities. One victim of this conservatism was Mahler's young friend, the composer Arnold Schoenberg. While Schoenberg was still able to please the audience with

129 Rosen (1975), 9.

130 Quoted in Janik and Toulmin (1973), 100. 
the Wagnerian style of the Gurrelieder, the reception that greeted moreadventurous compositions such as the song cycle Das Buch der hängenden Gärten (1908) and the one-act opera Erwartung (1909) was nothing if not chilly. A 1913 performance of works by Schoenberg and his pupils Alban Berg and Anton von Webern infuriated the public, who staged a riot that matched the famous premiere of Stravinsky's Sacre du Printemps in Paris that same year.

Like Kraus and Loos, both of whom he admired, Schoenberg wanted to shatter the system of worn-out aesthetic standards and expurgate musical language of ornamentation to the point where it became a force for pure expression. In music, it was tonality that determined this system of standards. Ever since the Renaissance, compositions had been built around a central triad. The primary means of expression in Western music consisted in the departure from this central triad (the tonic) to dissonant tones and triads, thereby creating harmonic tension, which was eventually to resolve again in consonance through a return to the tonic. Consequently, the tonal system creates a hierarchical relation between tones: dissonant tones and triads are suspended and transitional, thus demanding resolution, unlike consonant ones, which are resolved by definition. Carl Schorske argues that, for Schoenberg, this systematic hierarchy paralleled the hierarchy of Habsburg society: 'The tonal system was a musical frame in which tones had unequal power to express, to validate, and to make bearable the life of man under a rationally organized, hierarchical culture. ${ }^{131}$

In nineteenth-century compositions, most notably in Wagner's 'unending melodies', the return to the tonic had already been almost endlessly postponed. According to Schoenberg, it is just a final step to get rid of tonality altogether and to 'emancipate' the dissonant, as he calls it in his essay 'Opinion or Insight?' (1926). ${ }^{132}$ The emancipation of dissonance means its emancipation from the obligation to resolve in consonance: 'The individual parts proceed regardless of whether or not their meeting results in codified harmonies. ${ }^{133}$ Schoenberg names his new anti-systematic system 'free tonality' or 'pan-tonality', but it is better known by the name given by an unsympathetic critic: atonality.

It was never Schoenberg's intention or ambition to single-handedly overthrow the tradition of Western music. Rather, he considers his own work as only the final and inevitable phase of the destruction of a system already doomed. His biographer Willi Reich strikingly characterizes

131 Schorske (1981), 346.

132 Schönberg (1975), 258.

133 Quoted in Rosen (1975), 35 . 
him as a 'conservative revolutionary'. ${ }^{134}$ Indeed, Schoenberg regarded his revolution, not as the negation of the work of his great predecessors (Bach, Beethoven, Brahms, Wagner), but as its continuation. But it was a revolution nonetheless. After finishing Das Buch der hängenden Gärten, one of the first works in which he made use of free tonality, Schoenberg wrote in a letter:

But now that I am conscious of having broken through every restriction of a bygone aesthetic; and though the goal toward which I am striving appears to me a certain one, I am, nonetheless, already feeling the resistance I shall have to overcome; I feel now how hotly even the least temperaments will rise in revolt, and suspect that even those who have so far believed in me will not want to acknowledge the necessary nature of this development [...]. I am being forced in this direction.... I am obeying an inner compulsion which is stronger than any upbringing. ${ }^{135}$

Schoenberg, in other words, conceives of himself as an inevitable historical force, unstoppable even by his own will. The artist's will, he writes in the essay 'Problems of artistic education', has nothing to do with art. Artists do not will; they must. ${ }^{136}$

Music, according to Schoenberg, is a question of truth rather than beauty. It develops autonomously, propelled by its inner logic, as Hanslick had already argued. Consequently, the composer does not need to take the public into account. Whether the public enjoys their compositions should not be a matter of concern to them. The artist answers to no one but art itself. Schoenberg once said that the only advantage of having an audience is that it improves the acoustics of the concert hall.

Though it cannot be said that Schoenberg produced anti-art in the way the Dadaist did, he certainly was critical of the bourgeois institution of art, which in his view functioned as an entertaining and pleasant way to escape reality. Like his friend Adolf Loos, he argued that art should be uncomfortable and revolutionary: it should speak the truth, even if this truth is awful. The question was, however, whether art was wholly up to this task. Did art, and perhaps music in particular, not have the inherent tendency to please, to be beautiful?

134 Reich (1968).

135 Quoted in Rosen (1975), 7.

136 'Ich glaube: Kunst kommt nicht von können, sondern vom Müssen. Der Kunsthandwerker kann. Was ihm angeboren ist, hat er ausgebildet; und wenn er nur will, so kann er.... Aber der Künstler muß. Er hat keinen Einfluß darauf, von seinem Willen hängt es nicht ab' (Schönberg (1976), vol. 1, 165). 
Schoenberg tackled this problem in the opera Moses and Aaron, which he started between 1930 and $193^{2}$ but never finished. The libretto, written by the composer himself, is about the conflict between truth and beauty. Moses is burdened with the divine task of leading the people to the Promised Land, but he lacks the rhetorical power to convince the people of God's plan. Having been given this task by God, Moses replies: 'But my tongue is not flexible: thought is easy; speech is laborious.'137 God replies: 'Aaron will be enlightened, he shall be your mouth. ${ }^{1{ }^{1} 8}$ Aaron, however, though a skilled orator, is unable to grasp Moses' abstract thoughts and wishes. One way in which Schoenberg expresses this discrepancy between the divine idea and its verbal or artistic expression is by having Moses speak but not sing, while the role of Aaron is sung by a lyrical tenor.

From the outset, then, the brotherhood is doomed to end tragically. Aaron's faith in God, like the faith of the people of Israel, depends on outward signs: a rod that turns into a snake, a hand that becomes leprous only to heal miraculously seconds later. Neither he nor they can understand the true meaning of the divine, and Moses cannot make them understand, because, as Schoenberg presents it, the idea is by its very nature abstract and inexplicable.

The climax of the opera takes place in the second act, after Moses has ascended Mount Sinai to receive the Ten Commandments from God. The people grow restless during Moses' absence, demanding a sign from God. Aaron orders them to collect all their gold and says:

O Israel, I return your gods to you, and also give you to them, just as you have demanded. Leave distant things to One infinite, since to you the gods have ever-present and always-common substance. You shall provide the stuff; I shall give it a form: common and visible, imaged in gold forever. ${ }^{139}$

And so, a calf is built and presented by Aaron to the people of Israel. In the third scene of act two, Schoenberg stages the worshipping of the idol as a delirious religious event escalating into an orgy. People slaughter animals, tear them apart and devour raw meat. They get drunk, there is extravagant dancing, and finally even human sacrifice and ritual suicide.

Moses, descending from the mountain carrying the stone tables, beholds the scene and is enraged. He calls Aaron to order, but the latter defends 
himself and the people: 'No folk can grasp more than just a partial image, the perceivable part of the whole idea. Be understood by all the people in their own accustomed way. ${ }^{140}$ But Moses will not have it. He is unwilling to compromise the idea just to make it more understandable. In rage, he smashes the tablets with the Ten Commandments. At the same time, however, he becomes aware of the tragic fact that any expression of the idea must result in both an incomplete image and a damaged idea. Therefore, he cries out in despair:

Inconceivable God! Inexpressible, many-sided idea, will you let it be so explained? Shall Aaron, my mouth, fashion this image? Then I have fashioned an image too, false, as an image must be. Thus I am defeated! Thus, all was but madness that I believed before, and can and must not be given voice. $\mathrm{O}$ word, thou word, that I lack! ${ }^{141}$

In this opera, then, Schoenberg gives expression to his conviction that a work of art is by its very nature inadequate, for it tries to explicate the inexplicable truth. The words of Aaron, and the idol he builds, can merely hint at the truth, but can never fully grasp it. Again, this does not mean that for Schoenberg art is utterly without value, as it was for the Dadaists. It can have great value, but only on condition that it is as uncompromising and rigorous in its logic as possible, and does not yield to the whims of the public.

Schoenberg is often associated with the doctrine of l'art pour l'art, because of his uncompromising attitude towards the public and his emphasis on the autonomous development of the logic of the art form. Indeed, in some of his writings he mentions the doctrine approvingly. ${ }^{142}$ Nevertheless, we have seen that Schoenberg's notion of art has its roots in the critique of Viennese bourgeois culture, voiced by Kraus and Loos. According to these critics, art should renounce its function in this particular culture and this particular society; but that does not imply that it should strive to have no function at all.

Schoenberg's contribution to a project devised by his friend Adolf Loos is instructive in this regard: After the fall of the Habsburg Empire in 1919, Loos wrote 'Guidelines for an Office of Support for the Arts', in which he proposed a reformation of art practices for the benefit of a new democratic society. Loos, like the surrealists, wants to bridge the gap between art and

140 Wörner (1963), 189 .

141 Ibidem, 195.

142 See for instance the essay 'Neue Musik, Veraltete Musik, Stil und Gedanke', in: Schönberg (1976), 34 . 
life, though not through a revision of the arts, but through improvements in art education. He asked Schoenberg to write the section on music. In the resulting contribution, we read: 'Art education should improve the moral qualities of the pupil., ${ }^{143}$ For Schoenberg, in other words, music did not resist all functionality, but primarily a specific function it had in bourgeois culture, namely to be pleasing to the individual. Instead, he regarded music as the bearer of truth and argued that, only if this truth could be expressed in all its rigor could art have a moral and critical function.

\subsubsection{Avant-garde and modernism}

Both the surrealists and Schoenberg struggled with the heritage of the autonomous sphere of art in bourgeois society, and both tried to find appropriate responses to a culture that had become 'affirmative', to use Marcuse's term. Nineteenth-century aestheticism and the cult of pure beauty had, by the turn of the century, become a mere excuse for political indifference and impotence. The autonomy of art, according to these artists, functioned as a nature reserve in which the bourgeois individual could momentarily take leave of the worries of everyday life.

Both the surrealists and Schoenberg regarded themselves as surgeons of society. And since desperate ills call for desperate remedies, art as it had been conceived of up until then had to be radically altered. They denounced the function of art within society, and questioned the art forms that tradition had bequeathed to them. Schoenberg deconstructed the tonal system, which he saw as subjecting the individual tone to the hierarchy of harmony. The surrealist group revolutionized poetry, and rejected the novel form and sometimes even literature itself.

There are some notable differences between the two cases, too. Schoenberg's work, like that of the whole Vienna movement, was primarily about honesty and authenticity. Stripping art from false pretences was part of a critique of social and moral hypocrisy. Nevertheless, while Schoenberg was critical of the aesthetic tradition and explored the laws of the entire artistic medium all the way to its boundaries, he never actually crosses these boundaries. He and his pupils still produced 'art', which was performed in a concert or opera hall. The surrealist group, by contrast, did cross these boundaries: they mocked the 'divinity' of art and they looked down with contempt on the notion of genius and artistic creativity. While Schoenberg and the Viennese movement looked for a moral truth, the surrealists were 
after an epistemological and political truth. They refused to be conceived of as artists, regarding themselves as scientists and explorers of the subconscious. One would find them, not in the traditional theatres or literary salons, but rather in bars or vaudeville-theatres.

This difference between criticizing art from within and criticizing it from without marks, according to Bürger, the boundary between (high) modernism and the historical avant-garde. ${ }^{144} \mathrm{High}$ modernism explores the boundaries of the medium to the verge of incomprehensibility, but - since this exploration takes place within the autonomous sphere of art - it still accepts the institution of art in bourgeois society. Conversely, the historical avant-gardes (futurism, Dadaism, surrealism, and constructivism) criticize the institution itself, and make the place of art in society their target. Their primary objective is the reconciliation of art and life. From this follows an alternative aesthetic that entails collective production and reception in the shape of performances and manifestoes, and the denunciation of the very notion of the 'work' of art, as an organic whole, similar to nature.

Although Bürger's distinction is interesting, I think that it overlooks certain important similarities between high modernism and the historical avant-garde, and, furthermore, that his concept of avant-garde is too narrow. ${ }^{145}$ Contrary to what Bürger argues, high modernism incorporates a moment of anti-art as well. Its autonomy, especially in the case of Schoenberg, flows from a deep pessimism and is compelled by necessity. It emerges from the presumption that anything outside art is complicit with a false world. But since art by its very nature is 'false', namely illusory, it has to come out against itself. By ridding itself of falseness, it simultaneously expresses the wish that its own moral honesty might be part of the world too. As Jay Bernstein writes: "The anti-art moment of modernist works [...] enacts art's desire to be world and not art; but only as art, as semblance, can art evince that desire, perform it. ${ }^{146}$ This dialectical movement of modernist art will be extensively discussed once we turn our attention to Adorno's work.

144 Bürger (1984), Chapter 2.

145 For some interesting critiques of Bürger, see Lüdke (ed., 1976), Foster (1996) (most notably Chapter 1), and Murphy (1999) (most notably Chapter 1). For a different attempt to distinguish modernism from the avant-garde see Raymond Williams' essay 'The Politics of the Avantgarde' (in Williams (1989), 49-63). According to Williams, the difference between modernism and avant-garde lies, not in the content of their attack on bourgeois society, but rather in the greater hostility and militancy of the latter. Rosalind Krauss (1985), finally, argues that the avant-garde, in emphasizing the importance of originality and the 'new', remains confined within the paradigm of modernism.

146 Bernstein (2006), 247. 
Furthermore, in focusing on the institutional aspect of the avant-garde, Bürger misses the fact that, for instance, the socialist-utopian programme of the surrealist group brings it much closer to certain modernists than to other avant-garde groups, such as the Dadaists (who were to a large extent apolitical) or the Italian futurists (most of whom were Mussolini enthusiasts). ${ }^{147}$ Finally, there are a lot of artistic currents and individual artists that are not easy to place in either of Bürger's categories. It is not always that easy to determine in which cases an artist touches upon the boundaries of their art form, and in which cases they cross them. ${ }^{148}$ These remarks are not meant, however, to reject Bürger's distinction, merely to demonstrate that it should not be made as absolute or simple as he makes it. ${ }^{149}$ Since the positions of Benjamin and Adorno are sometimes said to parallel the avant-garde and high modernism respectively, we shall return to this issue in later chapters.

\subsection{Conclusion}

In the introduction to this chapter, I quoted Jameson: 'Always historicize!' Why is it necessary to historicize? Why is it so important to be aware of the contingency of our understanding of art? One important reason is that through historicization one absolves oneself of the duty of answering the question of what art is. One stops looking for a constant, transhistorical essence shared by all works of art, of all kinds and from all moments in history. The moment one realizes that one's concept of art is historically contingent, one will stop searching for a definitive answer to the question of what art is, and start asking: what is the place of art in our contemporary society?

147 See Egbert (1970) and Gay (2008).

148 Consider, for instance, the case of Alexander Rodchenko, who, in 1921 presents three monochrome paintings in the primary colours. He later commented: 'I reduced painting to its logical conclusion and exhibited three canvases: red, blue, and yellow. I affirmed: this is the end of painting. These are the primary colours. Every plane is a discrete plane and there will be no more representation' (quoted in Foster (1996), 17). Is this an example of a quasi-Dadaist 'performance' or the presentation of three monochrome paintings, that is of a 'work' of art? Is Rodchenko a modernist, taking the tradition and the artistic medium to its 'logical conclusion', or an avant-gardist, crossing the boundaries of the 'institution' of art?

149 I am more sympathetic to Hal Foster's distinction between a 'formal modernism plotted along a temporal, diachronic or vertical axis' and an 'avant-garde modernism that [...] favored a spatial, synchronic, or horizontal axis' (Foster (1996), xi). The advantage of this model is the possibility of crossover and hybrid forms, for which Bürger leaves very little room. 
The cases discussed in this chapter exemplify some crucial changes in the way art and artists have been conceived of in Western culture, in particular within the discussion of the autonomy or critical potential of art and the artist. More specifically, the cases illustrate the following two points.

First, both the institution and the concept of art we know and take for granted, are relatively young, and have their origins in specific historical (social and economical) circumstances. Kant's and Schiller's theories of the ideal of an autonomous art emerged at a moment in history when the autonomy of art also became a social fact. The decline in the power of the church and of aristocratic patronage released art and the artist from their servile role. Art entered the free market, giving artists the opportunity to experiment with form, but also presenting them with the necessity of reckoning with a public with which they shared neither taste nor tradition. This new social situation of the arts found its expression and justification in aesthetic notions such as the doctrine of l'art pour l'art and the theory of absolute music. Furthermore, it brought about the romantic cult of the genius; the notion that the artist was somehow elevated above the people and could see more and farther than ordinary folk. At the beginning of the twentieth century, this aesthetic discourse of pure art was challenged by the avant-garde and certain high modernists. The autonomy of art was itself unmasked as ideological and as 'affirmative' of bourgeois society. This did not mean, however, that the autonomy of art, in the sense of a distinct sphere in society, was seriously threatened by these challenges. ${ }^{15^{0}}$ Rather, the critique of the ideology of pure art made use of this autonomy.

This brings me to the second point I wanted to make in this chapter, namely that the notions of artistic autonomy and artistic critique, or of pure and committed art, were not simply opposed to each other, as is often assumed. The ideas of artistic autonomy and artistic critique emerged at more or less the same time in history, and have continued to exist side by side since. Schiller argued that art can be moral or political only as long as it is autonomous. The rejection by the doctrine of l'art pour l'art and of pure art of any function can itself be understood as a critical gesture towards the bourgeois principle of utility and the dominant logic of instrumental

150 As Schmidt writes in the case of literature: 'Gegen das Literatursystem wie im Literatursystem sind nur Revolten möglich, die das System durch Anwendung seiner Grenzoperationen entweder zu "Literatur" macht oder als Nicht-Literatur ausscheidet. Eine Revolution wäre nur möglich bei gleichzeitiger Umwandlung der Organisationsform der Gesamtgesellschaft, die dann einen anderen Typ von 'Literatur' hervorbringen könnte, über den sich unter den heutigen Bedingungen aber nichts sagen läßt. Die Abschaffung des Literatursystems ist so wenig intendierbar, wie es seine Entstehung im 18. Jahrhundert gewesen ist' (Schmidt (1989), 442). 
rationality. Conversely, the avant-garde's rejection of autonomy and its call for a reconciliation of art and life, are possible only from the standpoint of an autonomous domain of art. ${ }^{151}$ In short, the relation between artistic autonomy and artistic critique is understood properly only when we conceive of it as a historical and dialectical relation - historical because both positions have their roots in a specific socio-historical situation, namely the emergence of an autonomous sphere of art in society, and dialectical because each position depends and is premised on the other.

We have traced the roots of the modern concept of art and artists up to the beginning of the period between the two World Wars. As such, this chapter is also meant to situate and contextualize the debates between Benjamin and Adorno that take place in this period. To be sure, this does not mean there are no developments in the concept of art and the social situation of artists after that period. Still, I believe that several issues that I discuss here and that have emerged at the end of the eighteenth century and continued to haunt us ever since, are typical of modernity. Let me conclude this chapter by briefly pointing to three of them.

The first issue concerns the relation between artist and public. As soon as the artist became autonomous, towards the end of the eighteenth century, their relation to their public grew problematic. They could no longer count on the security of a tradition and taste they still shared with their aristocratic or clerical patrons. The new middle-class audience was anonymous, fickle, and uneducated. The artist might choose to serve this mass audience, or search for the favour of the elite market of aristocratic connoisseurs. Either way, the relation between the artist and his public was no longer self-evident.

We can see this time and again. Schiller went from considering the public his 'trusted friend' to seeing it as his enemy. We also find this hostility in Baudelaire, who compared his audience to a dog; and in Schoenberg, who conceived of his audience as little more than furniture in the concert hall. Alban Berg, Schoenberg's pupil, was rather worried about the successful premiere of his opera Wozzeck in 1925: if the public liked it that much, something had to be wrong with it. ${ }^{152}$ The idea that public success was a sign of artistic failure is still an important part of the discourse on art and artistic identity. It involves the dialectic of the increasing 'autonomization' of art and the growing appeal of mass culture, which will be the topic of

151 Of course, this is true only from the observer's perspective. As I have discussed, the avantgarde movements themselves had the destruction of the autonomous artwork as their objective. 152 This anecdote is told by Adorno $(16,86)$. 
the next chapter. It is an issue that today leaves its mark even on so-called 'popular culture' (for instance in the contempt for pop musicians who are said to turn 'commercial').

Surrealism wanted to reconcile art with life, but not with this life. The surrealists' audience - an audience emancipated both psychologically and politically - did not yet exist, in fact. Still, part of avant-garde art entails involving of the audience in the work, in the performance. This involvement increases with the possibilities of technological reproducing artworks (photography and film), and with new art forms such as performance art, installation art, community art, and interactive art - forms that thematize the inherently problematic relationship between the artist and the audience.

The second issue is the relation between the 'new' and the 'ever-thesame'. Modern art is dominated by what Heinich calls the 'regime of singularity'. ${ }^{153}$ Instead of following the rules dictated by the ancients, as artists up until the eighteenth and well into the nineteenth century did, the modern artist is aware of his autonomy - in the artistic rather than the social sense. Emancipation from court and church grants the artist the freedom to experiment, to explore the boundaries of the given medium. The 'new' becomes the number-one aesthetic value, voiced in Rimbaud's famous imperative: Il faut être absolument moderne. Simultaneously, the identity of the artist shifts, as we have seen in the case of Beethoven, from the able craftsman to the divine genius. And a genius, as Kant writes, does not follow rules, but dictates them.

In Romantic discourse, the notion of the genius came to stand for unbridled subjectivism and the expression of the most authentic and the deepest feelings. The avant-gardes, as we have seen, challenged these pretensions, and emphasized the banal, the everyday and the vulgar. Avant-garde artists proudly declared themselves to be talentless, and let their works depend on the subconscious, on coincidence and on repetition. Originality, creativity, and authenticity were regarded as part of a bourgeois aesthetic and were therefore rejected.

The third issue is the relation between beauty and truth. Art was not the only domain to become autonomous in the eighteenth century. Law, economics, science, politics, and so on also gained their independence. 'Autonomization' is the very 'grammar' of modernity, as Kant, Max Weber, and Jürgen Habermas have argued. Modernity is characterized by the differentiation of society into separate and relatively autonomous value spheres. While the Ancients had identified the beautiful with the true and the good, 
Kant separated it from utility, morality, and truth. Nineteenth-century aestheticism took things a step further by identifying utility with ugliness and rejecting any art that has an obvious political, moral, or pedagogical function.

One might still argue, however, that aestheticism identified beauty with truth, although not a scientific but a 'higher' truth, a truth not of this world. This has consequences for the kind of beauty that is valued. Increasingly, the ideal of classical harmony gave way to a kind of beauty that was unsettling, disorderly, and awe-inspiring: the sublime, as described by Burke and Kant. Whereas the beautiful, according to Kant, pleases directly, and produces 'a feeling of life's being furthered', the sublime involves 'a momentary inhibition of the vital forces' and pleases only indirectly. ${ }^{154}$

Kant associated the sublime primarily with natural phenomena, but modern art adopted it as the dominant aesthetic idea. Beauty itself became suspect, and this negative attitude was radicalized by twentieth-century high-modernism and the historical avant-garde. Instead of being a symbol of truth, beauty was not only considered inferior to the sublime, but was even opposed to truth. Beauty, on this view, is 'affirmative', a capitulation to a false world. This view resonated in Dadaist anti-art, in Breton's preference for bad writing, and in Schoenberg's portrayal of the conflict between the rhetorically skilled Aaron and the truth-bearing Moses. Beauty as harmony was replaced by an image that was considered to be more truthful: the imperfect, the fragmentary, the dissonant, the atonal, the absurd, the uncanny, and the grotesque. 